\title{
$\left.1\right|_{\text {Refracions }}$ \\ Beholding Uganda
}

\section{Does Uganda Have a History?}

This question is not supposed to be a deliberate insult to nearly forty million Ugandans, or to the decades of work undertaken by their historians and producers of culture; nor is it a throwback to an older idea that Africans possessed no such thing as 'history' until Europeans showed up to inject some purpose into their lives. Rather, the issue is whether, and to what extent, Uganda, as a national entity, has a history, and whether it is remotely possible to aim for an integrated view of the nation's past. In that sense, the question is a little more complicated than might first appear, and it very much depends on how we interpret it. Critically, for example, who exactly is part of that history? Even defining Ugandan history in the putatively straightforward terms of territorially delineated entity is problematic, given that the precise boundaries of the British Protectorate were not finally settled until 1926, when the administrative sector then known as Rudolf Province, in the far northeast, was transferred to Kenya. Similarly, West Nile district, in the northwest, was initially part of Belgian Congo, was then briefly administered as part of Sudan, and was only transferred to Uganda in 1912. Earlier still, a swathe of what would become western Kenya was originally considered part of the Uganda Protectorate, when the partition of the region was in motion, and only became part of Kenya in 1902. ${ }^{1}$ Even after 1926, the question of where 'Uganda' ends and somewhere else begins has been raised periodically: by Idi Amin in the late 1970s, for example, when the President - himself from a transnational group, the Kakwa, straddling the Ugandan-Congolese border in the northwest - laid claim to a chunk of territory south of the Kagera River in Tanzania. Indeed a few years earlier Amin had also demanded the return of western Kenya to Uganda, considering this swathe of the

${ }^{1}$ H.B. Thomas \& R. Scott, Uganda (London, 1935), 41. 
Kenyan Highlands an intrinsic part of his domain. In recent years, President Yoweri Museveni has questioned whether certain groups hovering nervously on the territorial peripheries of the nation are really Ugandan-symptomatic of one of the recurrent themes in the country's past, namely anxieties around claims to land, citizenship and belonging. And so questions of territorial delimitation do not necessarily lead to neat answers. Such is the problem with histories of nations - and to be sure, all nations have similar tales of peripheral ambiguity. To borrow the famous refrain of immigrant Mexicans to the United States: 'We didn't cross the border; the border crossed us'.

Then there is the very name of the place itself. Uganda is essentially a mispronunciation of Buganda - the state with which most visitors in the late nineteenth century engaged. Swahili traders, dropping the 'b' from most African place names in the interior, rendered Buganda thus, and the British followed suit. It meant (as did Buganda in the Luganda language) 'the place of the Ganda'. The irony is clear enough: the entire country which was placed under British rule, of which the Buganda kingdom was but one part - albeit an important one - was named after that kingdom, even though the territory encompassed dozens of groups which were distinct in language, culture, economy, political process. This is, to an extent, an accident of history, or more aptly of historical geography.

Nonetheless, leaving such ambiguities aside for the moment, the existence of Uganda's history as a sovereign entity since 9 October 1962, the date on which it achieved independence from Britain, seems undeniable. This was driven home in a very public fashion by the celebration and reflection that attended the nation's fiftieth birthday in 2012 - a noteworthy landmark, and one awarded the appropriate significance by the government, media, business and civil society alike. ${ }^{2}$ Several important narratives emerged in the course of the year - in speeches made, in essays written in the mainstream press, in public discussions printed and broadcast - which combined to apparently demonstrate the history of Uganda: an integrated, singular history; a national history, albeit one largely envisioned and articulated by a metropolitan

2 A number of glossy publications appeared to mark the occasion, and are a mine of 'local knowledge': see, for example, Fountain Publishers' Independent Uganda: the first 50 years (Kampala, 2012), and the Daily Monitor's collection of features and articles, Understand Uganda: 50 years of independence, 9 October 1962 - 9 October 2012 (Kampala, 2012). 
middle class. That history dwelt on anticolonial struggle against the British, and the heroes of that struggle; the monstrous darkness that enveloped Uganda during the 1970s under Idi Amin, and the violent aftermath; the resilience of Ugandans in overcoming war, dictatorship, poverty and the AIDS epidemic to build a national community of growing strength and confidence.

Yet what does it mean to write the history of an African nation in the early twenty-first century? The histories of nations are problematic affairs at the best of times - that is, even when there is a degree of received wisdom surrounding the existence of the nation itself, and a critical mass of literature pointing to the fact. There may be disagreement over the antiquity of the concept, and rival interpretations around the provenance and evolution of the accoutrements, the signs and symbols, of the nation. ${ }^{3}$ But the histories of African nations can be especially contorted and difficult projects, certainly if the aim of the latter is to demonstrate that nations themselves add up to rather more than the sum of their parts. What, after all, are nations in Africa, and how should one go about thinking about their historical trajectory and composition? ${ }^{4}$ It has been some time since histories of African nations were mainstream within the professional academy. But in the 1960s and 1970s, much pioneering Africanist historiography was framed in national - indeed sometimes nationalist - terms. ${ }^{5}$ Newly sovereign African nations were implicitly or otherwise awarded the gravity and ballast of antiquity, most notably by those scholars associated with or inspired by the 'Dar es Salaam school' in Tanzania. ${ }^{6}$ National historywriting arguably reached a highpoint with John Iliffe's Modern History of Tanganyika, widely regarded as one of the finest examples of the genre and one to which aspirant authors must routinely pay homage

${ }^{3}$ For example, M. Guibernau \& J. Hutchinson (eds.), History and National Destiny: ethnosymbolism and its critics (Oxford, 2004).

${ }^{4}$ See also R.J. Reid, 'States of Anxiety: history and nation in modern Africa', Past and Present, 229:1 (2015).

5 J. Lonsdale, 'The emergence of African nations', in T.O. Ranger (ed.), Emerging Themes of African History (Nairobi, 1968).

${ }^{6}$ Ranger (ed.), Emerging Themes; A.D. Roberts (ed.), Tanzania Before 1900 (Nairobi, 1968); I.N. Kimambo \& A.J. Temu (eds.), A History of Tanzania (Nairobi, 1969); B.A. Ogot (ed.), Kenya Before 1900 (Nairobi, 1976); A.D. Roberts, A History of Zambia (New York, 1976). For a critique, see D. Denoon \& A. Kuper, 'Nationalist Historians in Search of a Nation: the "new historiography” in Dar es Salaam', African Affairs, 69:277 (1970). 
in their own endeavours. ${ }^{7}$ Yet by the 1980 s few folk were writing the histories of nations, which had been displaced by transnational or regional history, ${ }^{8}$ or micro studies of specific bits of nations - the latter increasingly seen as obscuring more than they illuminated in terms of African agency and experience. The revolution which elevated 'history from below' to the mainstream likewise sidelined the nation as a unit of study. And after all, the crisis of legitimacy for the nation itself in Africa, by the 1980s, had depleted the confidence of an earlier generation, and accordingly delegitimised the defining of one's research in strictly national terms. ${ }^{9}$ More recently, the nation has been critically deconstructed in terms of claims on citizenship, and questions have been asked about whether they were, after all, the inevitable outcome of decolonisation. ${ }^{10}$ A subfield has recently begun to emerge around the study of national days and independence jubilees in modern Africa. ${ }^{11}$

It is true that much of the earlier 'national' work took for granted, very largely, that the nation itself existed; or at least the place existed and therefore it was assumed - quite rightly, up to a point - to be a legitimate exercise to tell the story of what had happened inside that place. These were, after all, sovereign entities and therefore they had histories. And so it is in more recent years, too, for the handful of scholars who have attempted similar projects. In Dan Branch's outstanding history of independent Kenya, for example, there is no existential crisis, no wrestling with whether or not a history of Kenya is

7 J. Iliffe, A Modern History of Tanganyika (Cambridge, 1979).

${ }^{8}$ A. Zimmerman, 'Africa in Imperial and Transnational History: multi-sited historiography and the necessity of theory', Journal of African History, 54:3 (2013).

${ }^{9}$ In arguably the most extreme case, Somalia, a change of title was required: in its first incarnation, I.M. Lewis's classic text was published as The Modern History of Somaliland (London, 1965), but in its final edition it had become $A$ Modern History of the Somali (Oxford, 2002), owing to the effective disappearance of the nation-state.

10 S. Dorman, D. Hammett \& P. Nugent (eds.), Making Nations, Creating Strangers: states and citizenship in Africa (Leiden, 2007); F. Cooper, 'Possibility and Constraint: African independence in historical perspective', Journal of African History, 49:2 (2008), and more recently his Africa in the World: capitalism, empire, nation-state (Cambridge MA, 2014); P. Geschiere, The Perils of Belonging: autochthony, citizenship and exclusion in Africa and Europe (Chicago, 2009).

11 See, for example, a recent special issue of Nations and Nationalism, 19:2 (2013), comprising especially pertinent essays by Carola Lentz, Christine Fricke, Konstanze N'Guessan and Izabela Orlowska. 
even a worthwhile and valid exercise. ${ }^{12}$ Kenya simply is, albeit in complicated ways. Perhaps this is a reflection of the self-confidence of the Kenyanist academy. But likewise in John McCracken's long-awaited and empirically robust study of Malawi, there is no time wasted on pondering the conceptualisation of Malawi as a unit of historical study; for McCracken, one of the world's leading experts on the place, the genealogies of Malawi are clear, and indisputable, and straightforwardly demarcated. ${ }^{13}$ This is striking, given the broader context of a postmodern turn against the nation as a unit of study in the Africanist academy; but then McCracken is a scion of the Dar es Salaam school, as he himself would cheerily admit. Gewald, Hinfelaar and Macola's critically reflective approach to Zambia is something of an exception, as is Alexander Johnston's study of South Africa, the latter part of a Bloomsbury series on the 'invention' of the nation; ${ }^{14}$ but a number of recent histories of nations have been fairly linear narratives which are generally unconcerned with deeper existential or ontological issues. ${ }^{15}$ More generally, Africa is seen as comprising a peculiar set of cases: arguably with the exception of Ethiopia, and certainly at one time Somalia singled out for particular attention, for example, by Ernest Gellner ${ }^{16}$ African nations are more often the exotic receptacles of a host of often distinctively potent subnational identities, which normatively threaten to rip apart the artificial national entity itself, or at least to claim it for themselves and use it for the advancement of their own agendas.

So, what about the entity itself, the place called Uganda? Does the nation itself have a history, or do we only tell the histories of the peoples who happen to live within those boundaries? Yoweri Museveni was in no doubt that Uganda did indeed have a history, if a short and troubled one, when in 2012, during the celebrations marking fifty years of independence, he publicly repented on behalf of all Ugandans for their manifold sins. ${ }^{17}$ Presumably, too, did George Wilberforce Kakoma,

12 D. Branch, Kenya: between hope and despair, 1963-2011 (New Haven, 2011).

13 J. McCracken, A History of Malawi 1855-1966 (Woodbridge, 2012).

14 J.-B. Gewald, Marja Hinfelaar \& Giacomo Macola (eds.), One Zambia, Many Histories: towards a history of postcolonial Zambia (Leiden, 2008); A. Johnston, South Africa: inventing the nation (London, 2014).

15 Bahru Zewde, A History of Modern Ethiopia 1855-1991 (Oxford, revised 2nd ed., 2001); T. Falola \& M. Heaton, A History of Nigeria (Cambridge, 2008).

16 E. Gellner, Nations and Nationalism (Oxford, 1983), 84-5.

17 'For the sins of Uganda I repent - Museveni', New Vision (Kampala), 18 October 2012. 
composer of Uganda's national anthem in the early 1960s, as well as the others involved in the design of Uganda's national signs and symbols. Certainly, for a generation of late colonial activists who later formed postcolonial Uganda's first governing elite, the nation was real enough. Grace Ibingira, notably, wrote of the 'forging', and the 'evolution', of the Ugandan nation from the 1890s onwards in a fulllength work of scholarly history in the early 1970s - though his vision was, not untypically, an increasingly disaffected one, reflected in his later novel about the travails of a 'fictional' African country. ${ }^{18}$ Judging from his letter to the UN Secretary-General in 1966, Kabaka Edward Mutesa II was less sure of the viability of 'Uganda': traditional 'tribal' authority, it seemed, was more important than any chimeric visions of nationhood. ${ }^{19}$ The further back we go into the colonial period, the more difficult the question becomes. At any rate, these unitary visions tended to be conceptualised as the products of a colonial modernity rather than rooted in the deeper past which was seen in more disconnected, fragmentary terms. Is it impossible, even undesirable, to think of Uganda as anything other than an empty receptacle into which are poured various ingredients, only to be emptied and refilled at regular intervals? Is Uganda merely - as one Ugandan informant once put it the hardware, only lacking the appropriate software? ${ }^{20}$

Uganda is not quite as artificial as might be supposed - and certainly no more artificial than many others, whether in Africa, Europe or elsewhere. ${ }^{21}$ It seems an apposite moment - following several decades of tumult and often rapid change across Africa in general, and certainly in Uganda in particular, and with a number of nations having now passed noteworthy jubilees - to consider the ways in which we might

18 Grace Ibingira, The Forging of an African Nation: the political and constitutional evolution of Uganda from colonial rule to independence, 1894-1962 (New York, 1973); and see his later Bitter Harvest: a political novel (Nairobi, 1980). Ibingira - involved in the design of Uganda's flag - was a leading figure in the UPC and served in Obote's government until his arrest in 1966. Released in 1971, he later went into self-imposed exile.

19 'Annexure to the Appeal by Kabaka Mutesa II to the Secretary-General of the United Nations, 11 March 1966', in D.A. Low (ed.), The Mind of Buganda: documents of the modern history of an African kingdom (London, 1971).

${ }^{20}$ Author's field notes and informal interviews, 6 August 2010.

21 See, for example, A.D. Smith, Myths and Memories of the Nation (Oxford, 1999), 163; first published as 'Gastronomy or Geology? The role of nationalism in the reconstruction of nations', Nations and Nationalism, 1:1 (1995). 
approach the history of an African nation. The foremost publisher in Uganda today, Fountain, was responsible for a brilliantly illustrated pictorial history of Uganda published in $2007 .^{22}$ One of the fascinating aspects of this book is that it was published to commemorate ' 150 years' of Uganda - and yet the selection of ' 1857 ' as a starting point is difficult to explain. It is not the accession of Mutesa I of Buganda, which took place around that time. However, it does appear to be rooted in the idea that Europeans first came to Uganda around this time, although it is a rather imprecise temporal hook on which to hang the argument: a man named Debono, a Maltese trader, was operating among the Acholi in the course of the 1850s, but Speke and Grant did not tread on 'Ugandan' soil until 1862, and Baker the following year. Whatever the case, the more important issue relates to the very legitimising presence of Europeans in the area - i.e., that 'Uganda begins' only when bazungu turn up to give it purpose, form and ultimately legality. This interpretation - privileging as it does the role of the exogenous - supposes that these are disparate peoples only brought together by the much more dynamic, historically meaningful, external forces that bring Africans into the world. In the process, these forces forge the place called 'Uganda', into which various peoples must squeeze themselves. It certainly raises an interesting question: when is Uganda? In one sense, perhaps, this is mere frippery: who cares when the place now called 'Uganda' comes into being, or that ultimately it appears to be foreigners who were responsible for it? On the other hand, it is vitally important, because it goes to the very heart of what an African 'nation' is - an externally created, artificial project which hapless natives must try in some way to make function, like a form of arranged marriage; or something rather more organic than that, with deeper historical roots, and linkages, and shared experiences, into which external influences become refracted, and co-opted. In truth, of course, 'foreigners' are usually involved in the making of nations, wherever we find them; and equally there is a level at which the national community only makes sense in contrast to others, to outsiders, to a line of vision which is by definition exogenous.

In wrestling with the question of when does one 'begin' a history of Uganda, I echo Karugire's argument that this is about 'shared historical experience' in the deeper past, not just since the late nineteenth

22 Uganda: a picture history, 1857-2007 (Kampala, 2007). 
century. ${ }^{23}$ It is not obvious why la longue durée should be any more problematic in Uganda than elsewhere in the world. ${ }^{24}$ Uganda can be interpreted as an economic, political and cultural 'community', or 'zone', which in fact has a degree of cohesion and interconnection in the deeper past. In other words, there is a precolonial crucible that becomes Uganda, a zone of interconnectedness in which the seeds of 'Uganda' are sown. The notion of a supposedly debilitating 'artificiality' arose around the time of decolonisation and its immediate aftermath, when it seemed that the borders of Uganda - and many other 'new' African nations - now encompassed a range of groups with apparently little or nothing in common and no experience of working together in the name of a larger national entity which bore little resemblance to political realities on the ground. ${ }^{25}$ It swiftly became clear that competition at the centre (and indeed at the edges) was over who would control this newly and externally defined space, inherited from colonial administrations. No doubt, enclosure potentially limited flexibility and placed restrictions on the earlier options of either violent confrontation or migration (although the story of Uganda contains plenty of both, in fact). Rather than having their conflicts played out through a multitude of channels and within a range of spaces, the newly anointed subjects/citizens of Uganda now had just one arena: that of the unitary state. Yet much was carried forward from the precolonial era within and around that 'artificial' space. Certainly, it should come as little surprise that enclosure brought about heightened levels of violence in postcolonial Uganda. This was the result, essentially, of what might be termed political claustrophobia. A political culture built around the notion that 'winner takes all' quickly developed within the confined space that was the nation-state, and panic - manifest in extraordinary brutality towards, and between, citizens - became part of that political culture. The regime of Idi Amin perhaps best demonstrates

23 S. Karugire, A Political History of Uganda (Nairobi, 1980), 1-2.

24 See Jeremy Black, Contesting History: narratives of public history (London, 2014).

25 Contemporary analysis is provided in Thomas Hodgkin's classic Nationalism in Colonial Africa (London, 1956), and the core themes were subsequently developed in the work of, among many others, James Smoot Coleman - see Nationalism and Development in Africa: selected essays (Berkeley CA, 1994)and Basil Davidson, whose thinking culminated in The Black Man's Burden: Africa and the curse of the nation-state (London, 1992). 
this. Yet while in some respects precolonial mechanisms for conflict resolution were undermined, much of the violence itself was actually precolonial in origin - most obviously that involving the hegemonic southern kingdoms, especially Buganda. Cultures of violence and militarism long pre-dated the formal creation of 'Uganda', and the fault lines which opened up in the years following Uganda's independence in 1962 were in fact of considerable antiquity. And so, too, were the histories of cultural interchange and reciprocal inspiration, and the economic networks which bound together diverse communities to mutual advantage. If war was old, then socio-economic connectivity was just as deep-rooted.

Terrain has longue durée, too, as Braudel argued, ${ }^{26}$ and it is perhaps the easier of the tasks before us to define Uganda in terms of its physical geography. Broadly, the territory itself is plateau land, enclosed by a rim of mountains on its western and eastern flanks, and its general elevation rendering it relatively more temperate in climate than much of the surrounding region, despite the fact that it straddles the equator. ${ }^{27}$ Uganda lies almost completely within the Nile basin, and around 16 per cent of its total area is open water and swampland, including the major lakes Victoria, Albert, Edward and Kyoga which ring the relatively better-watered southern half of the territory. The White Nile, indeed, in many ways defines and cuts across the territory, flowing out of Lake Victoria at Jinja, intersecting with the western end of Lake Kyoga before moving into Lake Albert, from whence it flows northward out of Uganda and into South Sudan. The southern half of Uganda experiences heavier rainfall, with two main rainy seasons between March and June and between September and November, and this - combined with the prevalence of lakes and waterways - means that southern Uganda has the heavier vegetation, including savannah grasslands and some equatorial forest, and much richer soils. Thus the south has historically been able to support extensive farming and sizeable population densities. In the north, by contrast, rainfall is much lower, and certainly less bimodal: the hot, arid northeast, notably,

${ }^{26}$ Fernand Braudel, The Mediterranean and the Mediterranean World in the Age of Philip II (Berkeley \& Los Angeles, 1994; 1st pub., 1949).

27 For more detailed overviews of Uganda's physicality, see Thomas \& Scott, Uganda, Chapters $2 \& 3$; and in a regional context, S.J.K. Baker, 'The East African environment', in R. Oliver \& G. Mathew (eds.), History of East Africa vol. I (Oxford, 1963). 
experiences only one annual rainy season (March-April). Northern Uganda has much thinner vegetation, and in the dry plains in the northcentral and northeast zones, pastoralism is predominant. Of course even within these broad areas, there is considerable - even dramatic variation, meaning that despite Uganda's relatively compact size it encompasses extraordinary environmental and climatic diversity: the highland regions of the Ruwenzori mountains of the southwest, a political and cultural frontier land of historical significance, on the upper reaches of which there is a permanent layer of snow, and high rainfall and lower temperatures on the lower hills; the remarkable subsnowline landscapes of Mt. Elgon in the east; the dry grasslands of Ankole and the Masaka area, characterised by undulating hills and relatively low rainfall; the moist northern and western strip around Lake Victoria with forest (including the Mabira belt) stretching from Jinja to the Kagera River; the hot and dry Karamoja area in the northeast. The general pattern for the rest of Uganda, however, is plateau land covered by tree savannah, enjoying sufficient rainfall for settled agriculture. Again farming - and, of course, fishing, one of the oldest economic activities in the area - has been greatly assisted by the omnipresence of lakes and rivers. With the exception of the Nile itself, and the clear streams found in the mountainous areas and on the slopes of the western rift valley, rivers are mostly sluggish swamps, such as the Kafu, Katonga, Sezibwa and Mpologoma.

Communities moved into and adapted their economies to particular environments, often nestling alongside rivers and streams or hugging lake shores. At this point, it is important to emphasise the complexity of Uganda's human environment, no less than its physical composition. Defining and enumerating 'ethnic groups' in a rigid sense is dangerous and misleading, ${ }^{28}$ but there are more than two dozen reasonably clearly defined and numerically significant ethnic groups in Uganda today, some of which spill over into the neighbouring

28 There is a substantial literature on the supposed modern 'invention', and the 'reimagining', of ethnic identity, in Uganda as elsewhere: see, for example, Crawford Young, The African Colonial State in Comparative Perspective (New Haven \& London, 1994), 232-4; and Iliffe, Modern History, 323. Some, however, have argued for a more longue durée approach: notably J.-P. Chretien \& G. Prunier (eds.), Les ethnies ont une histoire (Paris, 1989), P. Chabal and J.-P. Daloz, Africa Works: disorder as political instrument (Oxford, 1999), 57, T. Spear, 'Neo-traditionalism and the limits of invention in British colonial Africa', Journal of African History, 44:1 (2003). 
territories of Congo, South Sudan, Kenya, Tanzania and Rwanda. Lake Kyoga and the arc of the Nile between Kyoga and Lake Albert marks, in a necessarily approximate sense, the division between the Niloticand Sudanic-speaking north and the Bantu-speaking south. In the latter zone, Bantu-speakers - entering Uganda over the course of the first millennium BCE and the first millennium $\mathrm{CE}^{29}$ - have been the most numerous of Uganda's language and culture groups, not least because of their settlement in the wetter, more fertile parts of the territory, often close to the rivers and lakes described earlier. These now include the relatively numerous Ganda, Soga, Nyankole (including the Iru and Hima groupings), Nyoro, Kiga, Gwere, and a number of smaller groups. The Sudanic groups in northwest Uganda include the Lugbara and the Madi, and represent the remnants of what was probably a much more widely dispersed language and culture bloc which at one time occupied much of northern Uganda. They were, however, either absorbed or displaced by the Nilotic populations now inhabiting much of the country north of lakes Kyoga and Albert. These are divided into so-called 'Western Nilotes' - notably Acholi, Kumam, Padhola, Langi, Alur and the 'Eastern Nilotes', including Karamojong, Teso, Pokot, Kakwa and Sebei, who are now included under the generic name 'Ateker'. Even these terms do not always describe fixed or cohesive ethnicities, but rather are umbrella terms - 'Karamojong' is perhaps the best example ${ }^{30}$ - denoting several autonomous and distinct subgroups. Several Nilotic groups are geographic outliers - that is to say, they are now located some way from the main linguistic and cultural clusters - owing to economic or political migration over the last 200 years or so.

Conceptualisations and definitions of Uganda have long been dominated by the southern monarchical states, whose histories cast a mightily long shadow across the history of the nation as a whole. To what extent can we take the analysis and the narrative away from the south and its territorial, centralised monarchies, and back towards the putative peripheries - especially the north, beyond Lake Kyoga? These have

29 David Schoenbrun, A Green Place, A Good Place: agrarian change, gender, and social identity in the Great Lakes region to the $15^{\text {th }}$ century (Portsmouth, NH, 1998), 41-5.

30 Ben Knighton, 'Globalizing trends or identities through time? The longue durée in Karamojong ethnography', Journal of Eastern African Studies, 1:3 (2007), 478 fn. 1. 
certainly been overlooked by most archivally minded historians, and only a little less so by anthropologists; and yet those areas comprise an enormous chunk of Uganda's total area - at least half, if not a little more. There is an abiding fascination with the structure and political cultures of the monarchical states of the interlacustrine forest zone, and with the archival access associated with such states. In essence, this is about how knowledge is ordered. At the same time, however, it is not purely about the imposition of European visions of worthy and unworthy Africans. The respective social structures in the south and in the north were differently equipped to deal with the various challenges and opportunities encroaching from the outside world. The Acholi, like the Ganda, were heavily involved in the slave trade, for example; but unlike the Ganda, the Acholi did not inhabit an adequately arable zone, one in which commercial agriculture could flourish, and therefore were not able to respond positively to the economic directives of the colonial era. Instead, the district became an exporter of labour and a source of militarisation through recruitment into the colonial army. This was a classic case of internal underdevelopment. Even more stark is the case of the Karamojong, who suffered the vagaries of, and statelevel hostility to, pastoralist economics. This underdevelopment was undergirded by a scholarly apparatus from the 1950s onwards, and a colonial political mindset before that, which was fixated with particular forms of governance, economic 'growth' and the minutiae of Ganda politics and political intrigue, and with the finest nuances of political opinion, activism and access to the 'native mind', especially with a view to understanding indigenous conceptions of 'modernity'. ${ }^{31}$

Northern groups have at least an equal claim on the making of modern Uganda as do those in the south - through the absolutely critical role northern migrations have played in Uganda's deeper past, not least as the fount of much political innovation; in the provision of labour underpinning the modern Ugandan economy; in the modern dominance of the north in military terms, in colonial and (until the late 1980s) postcolonial armies. Ultimately, the Anglo-Ganda alliance at

${ }^{31}$ It is a preoccupation which underpinned early scholarship: see, for example, the very different approaches in K. Ingham, The Making of Modern Uganda (London, 1958), D. Apter, The Political Kingdom in Uganda: a study in bureaucratic nationalism (Princeton, 1961), L.A. Fallers (ed.), The King's Men: leadership and status in Buganda on the eve of independence (New York, 1964) and D.A. Low, Buganda in Modern History (London, 1971). 
the start of the twentieth century imagined the north as the internal 'other', and this has been perpetuated by the current government assisted considerably by the war against Kony and the LRA. In sum, to borrow a phrase from an influential economic history paper of some years ago, ${ }^{32}$ this is a question of 'reversal of fortune', from north to south. Uganda in origin owes an enormous amount to the north in terms of politics, culture, religion; but the south has latterly come to dominate in political and economic terms, in part the curse of geopolitics and nature, but largely the result of particular hegemonic visions of political and economic modernity. And so in some ways it is no coincidence that the first twenty years of Uganda's independence were dominated by northern governments with self-consciously modernist, unitary and patriotic visions of Uganda.

In Uganda - and elsewhere in Africa - there has been much patriotism, and self-styled patriots have particular ideas about the spatial territory that is the nation. But approaches to a putative national past have been rather more diffident. ${ }^{33}$ Uganda is cut across by tensions and conflicts - ethnic, socio-economic, regional, spiritual - but is also characterised by shifting coalitions and alliances, by lines of cooperation and productive contact. What does all this mean, not simply for the daunted author seeking interpretative synthesis, but for conceptualisation of the historical nation itself? Should African nations even have or want histories? So what if they don't have national histories stretching back to the precolonial era? Perhaps this really is a question of developing the history they need, and that serves its purpose. Yet of course the peoples living within the nation $d o$ have precolonial histories, and they do matter; their separation from that of the larger political space - the nation - seems a dangerous and unhealthy thing. Above all, there is the question of organic plurality, and the argument that it is only when the deeper past is explored and perhaps even celebrated that the modern nation can ultimately achieve plurality, inclusivity, rootedness, stability. These are not uniquely African questions - comparing the situation in Uganda with the various national history wars since the 1990s around the world, at a time when in Europe, for example, national history had

${ }^{32}$ D. Acemoglu, S. Johnson \& J. Robinson, 'Reversal of Fortune: geography and institutions in the making of the modern world income distribution', The Quarterly Journal of Economics, 117:4 (2002).

33 Reid, 'States of Anxiety'. 
supposedly had its day. ${ }^{34}$ And 'national histories' do have enormous implications: for self-identification, plurality, inclusivity, ideas about development, participation, contribution and immigration/migration. An integrated, holistic national history that makes everyone happy is undoubtedly pure fantasy: like unicorns. But in a sense that is not really the point. The exercise itself is the thing, and it is an exercise in temporal demography: who and what populates the past?

It is also worth reiterating the point that all nations have violent roots and are characterised by violence; this is not - despite some popular and enduring misconceptions - something that is a peculiarly 'African' condition, nor is the so-called 'tribalism' that threatened to consume Uganda between the 1960s and the 1980s, and in some ways still does. There are plenty of fissures and fractures and conflicts, of course. Like all nations, Uganda is the product of violence and inequity; like all nations, too, Uganda is the product of a complex network of frontiers and rough edges, which act as buffers against neighbours but which are also places of creativity and loci of control. The state can control troublesome people there, but those troublesome people also contribute ineffably to the nation's sense of itself, and its power, and very often in very practical terms; those populations paradoxically not only act as the necessary 'other' but often contribute the manpower to the economic projects and the military and security apparatus necessary to the nation's own development and self-management. At the same time, however, successive regimes have struggled to realise and articulate the nation, with the result that history wars have very much defined modern Ugandan politics and culture. Historical culture, historical consciousness, has so often been mobilised not at the national level but a range of sub-national levels: the past has had many uses for the component groups of the nation. But ultimately, as an interconnected, discrete field of reciprocal engagement - both violent and otherwise - yes, Uganda has a history.

\section{Uganda Studied}

The story of Uganda's birth and growth can be usefully encapsulated in a series of generational snapshots, beginning in around 1900, when

34 See, again, Black, Contesting History. 
administrator Harry Johnston was not only able to write of the problems but also of the possibilities of the newly-formed Uganda Protectorate. At the heart of his optimistic assessment - born, naturally, of a confidence in the British imperial mission - was an emphasis on the positive role of Christianity, which had been introduced barely a generation earlier, and on the civilising potential of the kingdom of Buganda. ${ }^{35}$ The latter, whose political sophistication had so impressed European visitors, sat at the privileged centre of the colonial order. Much progress could be claimed even since Frederick, later Lord, Lugard's description of Britain's role in the region just a decade beforeLugard who had made no small contribution to Ugandan history himself as the man who had maintained the Imperial British East Africa Company's precarious presence in the area, and who had ultimately ensured early Anglo-Ganda collaboration in the state-building project underway in the course of the 1890s. ${ }^{36}$ By the 1930s, Uganda's rapid development was captured in a comprehensive survey by Thomas and Scott, still a rich historical resource, in which they were able to describe a territory of wondrous diversity but one in which wild terrain was being traversed by railways and macadam roads, and in which commercial agriculture was conquering the African bush; and of course they found time to include information on the best places to view wildlife or - if one preferred - to shoot it. ${ }^{37}$

A generation later, Uganda was on the cusp of independence, and while the historian Kenneth Ingham could write assuredly in 1958 of the 'making' of Uganda in what was one of the first modern histories of the country, ${ }^{38}$ others focused on what seemed to be intractable problems for the fledgling nation. The journalist Harold Ingrams wrote of nationhood as an 'elixir', but in his 1960 book that potion remained elusive, and it was the 'crisis' of nationhood that seemed set to dominate Uganda's political horizon for the foreseeable future. ${ }^{39}$ To Ingrams, as to many other observers of Africa in the late colonial period, diversity was a problem. To Scott and Thomas, it was something marvellous, and their Uganda had been an exotic colonial menagerie; now, however, on the cusp of nationhood, multiplicity

35 Sir H.H. Johnston, The Uganda Protectorate, 2 vols (London, 1902).

${ }^{36}$ F.D. Lugard, The Rise of our East African Empire, 2 vols (Edinburgh \& London, 1893).

37 Thomas \& Scott, Uganda. $\quad{ }^{38}$ Ingham, Making of Modern Uganda.

39 H. Ingrams, Uganda: a crisis of nationhood (London, 1960). 
threatened to tear the nation apart even at the point of its creation. Ingrams was writing at the close of a tumultuous decade, in which Buganda had demanded ever greater autonomy from Uganda, and the Kabaka? (king) had been exiled to London for two years for the trouble he had caused the British. And that was the problem: Buganda was, in effect - and certainly many Ganda saw the kingdom as - a nation within a nation, and the political scientist David Apter explored the issue of 'neo-traditionalism' in his study of the kingdom in the same period. ${ }^{40}$ Of particular interest was the ethno-nationalist organisation Kabaka Yekka ('The King Alone'), which agitated for autonomy within and even secession from Uganda. Buganda certainly drew much of the scholarly gaze in the early 1960s, as it seemed the ancient state held the key to the larger nation's success or failure. ${ }^{41}$ More broadly, the concern in this period was the supposed antagonism between nation and tribe: would 'tribalism', of which Buganda was the aggressive exemplar, undo the nation? ${ }^{42}$

Fast forward another quarter-century, and the answer was no, but it had come pretty close. If the 'moment' in the late 1950s and early 1960s had seen the nation as, at best, a work in progress, then the late 1980s and early 1990s found Uganda battered and barely afloat. The nation had been used and abused in the interim, wracked by violence and a succession of catastrophic leaders; little wonder, then, that the literature in our snapshot for the period was all about reconstruction, moving beyond trauma, rebuilding lives and institutions. Thus a terrific freeze-frame is provided by Paul Wiebe and Cole Dodge in an edited collection surveying the devastation and contemplating possible solutions. ${ }^{43}$ Pioneering collections of essays assembled by Michael Twaddle and Holger Bernt Hansen likewise considered a range of social, economic and political challenges and prospects. ${ }^{44}$ Phares Mutibwa's history of Uganda since independence, written at a critical moment in that very history, was unsurprisingly boisterous,

${ }^{40}$ Apter, Political Kingdom. $\quad{ }^{41}$ For example, Fallers (ed.), The King's Men.

42 P.H. Gulliver (ed.), Tradition and Transition in East Africa: studies of the tribal element in the modern era (London, 1969).

43 P.D. Wiebe \& C.P. Dodge (eds.), Beyond Crisis: development issues in Uganda (Kampala, 1987).

44 Notably, for this period, M. Twaddle \& H.B. Hansen (eds.), Uganda Now: between decay and development (London, 1988) and M. Twaddle \& H.B. Hansen (eds.), Changing Uganda: the dilemmas of structural adjustment and revolutionary change (London, 1991). 
dramatic, but also markedly reflective, characterised by a sense, almost, of bemusement that Uganda had somehow survived. ${ }^{45}$ It also concluded on an optimistic note, rooted in a sense that Yoweri Museveni and the NRM might just have discovered the elixir of which Ingrams had written thirty years earlier. But their solution was a combination of careful political management - restoration of the kingdoms, no-party elections - and economic liberalism: the nation was to be restored by the smelling salts of the free market, and Uganda under Museveni was poised to become the poster-child of structural adjustment and beloved of international financial institutions and the donor community. This brings us to our own 'moment'. Assessments of Museveni's Uganda are at best ambivalent, and mostly hinge on the problem that it is, still, Museveni's Uganda: the complexity and hybridity of the President's creeping authoritarianism; simmering internal (and external) conflicts and the potential for their escalation, as well as for their containment; the looming challenges for an oil-producing nation. ${ }^{46}$ Underlying these analyses, again, is a sense - even if not explicitly articulated - that Uganda has come some way and achieved a great deal, but once more the country is on the approach to a critical moment, potentially more significant than anything the NRM has yet faced. Our own era is characterised, then, by mounting anxieties. A Whiggish reading of this literary romp might suggest a nation increasingly at ease with itself, and certainly ever more resilient: at each stage, naturally enough, its historical ballast has grown weightier, and while experience can and has been divisive, it has also forged an ever-stronger national community. Yet the diverse human experiences encompassed within the relatively compact space that is Uganda have inspired several generations of writers, autochthonous and foreign, scholarly and otherwise; and that vast body of literature is suggestive not of an integrated national past, but of a rather more atomised, fragmented set of histories.

45 P. Mutibwa, Uganda since Independence: a story of unfulfilled hopes (London, 1992).

46 A.M. Tripp, Museveni's Uganda: paradoxes of power in a hybrid regime (Boulder CO, 2010); S. Lindemann, 'Just another change of guard? Broad-based politics and civil war in Museveni's Uganda', African Affairs, 110/440 (2011); International Crisis Group, Uganda: no resolution to growing tensions (Africa Report No. 187, Nairobi/Brussels, 5 April 2012); B. Shepherd, Oil in Uganda: international lessons for success (Chatham House, London, February 2013). 
We can trace that body of literature to the middle decades of the nineteenth century. It has become something of a shibboleth that late nineteenth-century Europeans routinely declared Africa to have 'no history' worth speaking of - a judgement based largely on the lack of written documentation in the vast majority of African societies, sub-Saharan at any rate. ${ }^{47}$ The reality is a little more complex. In fact a great many Europeans were deeply interested in Africa's history between the 1870s and the 1900s, and it was only with the consolidation of colonial rule in the 1910s and 1920s - and the increasing supremacy of economic agendas - that the continent's past became severed from its supposedly stunted present. During the era of the partition itself, the past mattered a great deal - and in particular, the histories of states, for it was this political form which was the mark of relative civilisation, and with which Europeans could most readily empathise and ultimately establish functioning relations. Historical enquiry was part of a process by which Europeans sought legitimate and stable partners in the civilising mission. As such, explorers, missionaries and sundry adventurers frequently looked for the centres and symbols of power and sovereignty, and embarked on quests for ancient lineages and genealogies; these were aspects of social structure which also, of course, denoted nobility and aristocracy, and which were deemed critical if the imperial mission was to have any chance of success. Some kind of historical evolution was at least implicit in the discovery of hierarchy, of rank and status, for this was the sine qua non of the semi-civilised state, even if a culturally and geographically beleaguered one. Europeans were thus especially fixated with emperors, kings, 'big men' and princely heredity; their gaze was drawn inexorably towards indications of despotism, absolutism, savage omnipotence - the peculiar product of Africa's turbulent historical trajectory. In their turn, African historians themselves both informed European visions of the past, and would enter this dynamic epistemological marketplace on their own account.

In terms of written commentary, Ugandan historiography dates to the mid-nineteenth century. On their joint expedition across presentday Tanzania in the late 1850s, Richard Burton and John Hanning Speke were both told of powerful kingdoms north of Lake Victoria,

${ }^{47}$ For example, J. Vansina, Paths in the Rainforests: toward a history of political tradition in Equatorial Africa (London, 1990), xi. 
and in particular of the dominant kingdom of Buganda; and although neither travelled there on this occasion, each provided sketchy surveys of Buganda's recent history and current state in their respective accounts of the expedition. ${ }^{48}$ These are, in effect, the first contemporary recordings of 'Ugandan' history, albeit second-hand. But it was Speke, on his follow-up expedition to the region to prove that the Nile did indeed flow out of Lake Victoria, who was the first European to visit both Buganda and neighbouring Bunyoro, in 1862, and who in many respects laid the foundations of regional historiography. ${ }^{49}$ This time he travelled around the western side of Lake Victoria, through Buddu ssaza ('county') and into Buganda, where he stayed for six months; thereafter, he headed north, through Bunyoro and thence homeward towards Egypt. His account of this journey contained extensive historical data and speculation, of variable quality and utility. Speke provided the first king-list for Buganda, for example - it comprised eight names - and an account of state-formation in the area, a process which he famously ascribed to the arrival from the north of lighter-skinned, and therefore more intelligent and culturally advanced, invaders at some point in the distant past. This would become known as the 'Hamitic myth', and would distort comprehension of the region's history for many decades. ${ }^{50}$ The idea of Buganda's comparatively advanced civilised state, $v i s-\grave{a}$-vis the surrounding states and societies, would prove remarkably durable, and indeed Speke's writings were representative of a general European fascination with the kingdom at the expense of others in the area.

Thus began a relationship conducted not only in the 'unknown' centre of the continent but carried out, too, along the darkest borderlands between fact and fiction. The European connection was by no means Ugandans' oldest external relationship, but it was of escalating and eventually enormous significance. Drawing on 'oral information', Burton's 'northern races' - as he described the inhabitants of Buganda, Bunyoro and Karagwe - were

48 R. F. Burton, The Lake Regions of Central Africa (first published in 2 vols, London, 1860; republished in one volume, New York, 1995); J. H. Speke, What Led to the Discovery of the Source of the Nile (Edinburgh \& London, 1864).

49 J. H. Speke, Journal of the Discovery of the Source of the Nile (Edinburgh \& London, 1863).

50 C.G. Seligman, Races of Africa (London, 1939), perpetuating the fundamental idea, was republished several times, and achieved a fourth edition in 1966. 
superior in civilisation and social constitution to the other tribes of Eastern and Central Africa.... [T] hey have built extensive and regular settlements, and they reverence even to worship a single despot, who rules with a rigor which in Europe would be called barbarity. Having thrown off the rude equality of their neighbours, they recognise ranks in society; there is order among men, and some idea of honour in women; they add to commerce credit, without which commerce can hardly exist; and they hospitably entertain strangers and guests... Their heads are of a superior cast; the regions where the reflective faculties and the moral sentiments, especially benevolence, are placed, rise high; the nose is more of the Caucasian type... and the expression of the countenance is soft, kindly, and not deficient in intelligence. ${ }^{51}$

In other words, their heads were the right shape, they had a strong king and their women were chaste. A few years later, Speke entered the kingdom of Buganda. Somewhere in southern Buddu, he fell in love:

I felt inclined to stop here a month, everything was so very pleasant. The temperature was perfect. The roads, as indeed they were everywhere, were as broad as our coach-roads, cut through the long grasses, straight over the hills and down through the woods in the dells - a strange contrast to the wretched tracks in all the adjacent countries.... Wherever I strolled I saw nothing but richness, and what ought to be wealth. The whole land was a picture of quiescent beauty, with a boundless sea in the background. ${ }^{52}$

And so Speke felt able to imagine a history in which the region had been populated by a conquering superior race, Caucasian in provenance, who had fashioned a crude but markedly superior culture out of the lush landscape, and imposed order on their little corner of the world. It was a particular European interpretation of Uganda's immigrant past which proved remarkably enduring. ${ }^{53}$ It was a myth - one that sat well with nineteenth-century British historical thought, with an emphasis on the inexorable sweep of civilised conquering foreigners; it was a gross, if not wilful, miscomprehension of the dynamics of the region's deeper past, which was altogether more complicated. Meanwhile, Speke's roads were profoundly important, and loaded with meaning; they appealed powerfully to the Victorian mind, and spoke to a supremacy in intellect and outlook. For Britain, an especially potent and enduring vision of the Ugandan nation was thus created on the

${ }^{51}$ Burton, Lake Regions, 391-2. $\quad{ }^{52}$ Speke, Journal, 274.

53 Ibid., Chapter IX, 'History of the Wahuma'. 
well-travelled highway running west of Lake Victoria; an idea formed of the natural political and moral order of things between Speke taking leave of the king of Karagwe, Rumanika (who he also rather liked), in December 1861, and his arrival at the Ganda royal capital in January 1862. Uganda's modern reordering lay here, in terms of the external legitimacy which was to prove vital in consolidating a particular vision of the territory.

Farther north, meanwhile, Baker's descriptions of his experiences focus on apparently ceaseless internecine conflict among the Acholi, and the childish, pathetic behaviour of Kamurasi of Bunyoro. At one point, having supposedly protected the kingdom from slave-raiders, Baker finds himself elucidating to a quivering Kamurasi the power of the British flag: 'I explained that the flag was well known, and might be seen in every part of the world ... Seizing the opportunity, he demanded it, saying, "What shall I do when you leave my country and take that with you?... Give me the flag, and they will be afraid to attack me!"' Baker refused. Kamurasi, '[t]rue to his uncontrollable instinct of begging ... replied, "If you cannot give me the flag, give me at least that little double-barrelled rifle that you do not require as you are going home...." "54 His description of Bunyoro as a land of violent primitives hostile to the outside world stuck, and proved influential into the late nineteenth century and beyond. And in Speke's account, too, Kamurasi is oddly childlike, insecure, always unfavourably compared to his great rival Mutesa in Buganda. Of course, no one is spared the racialised characterisations which indicate the savage immaturity evident in all Africans; Mutesa, for example, is frequently depicted by Speke as a brutally unstable young man, the product of a society which is nauseatingly cruel, its members seemingly impervious to the suffering of others. ${ }^{55}$ But in the British mind there is a great gulf between Buganda and everyone else, and it is the receptiveness of the former, their willingness to become something else, to improve, which is of cardinal importance. It is captured in the journalist and explorer Henry Morton Stanley's account. In 1875, Stanley purportedly, and singlehandedly, converts a now-matured Mutesa to Christianity; and the kabaka declares to the explorer, 'Stamlee ... say to the white people, when you

${ }^{54}$ S. Baker, The Albert N'yanza: Great basin of the Nile and explorations of the Nile sources, 2 vols (London, 1866) II, 435.

55 Speke, Journal, 356, 412; A. Kagwa (tr. \& ed. M.S.M. Kiwanuka), The Kings of Buganda (Nairobi, 1971), 140-41. 
write to them, that I am like a man sitting in darkness, or born blind, and that all I ask is that I may be taught how to see, and I shall continue a Christian while I live'. Stanley, famously, did just that. ${ }^{56}$

The Church Missionary Society responded to Stanley's missive, as did - much to the annoyance of the Anglicans - the French Catholic order based in Algiers, the White Fathers, who arrived two years after the CMS, in $1879 .{ }^{57}$ The souls that each would win in the decade that followed were, in political terms, critical to the balance of colonial interests and the very nature of the territory itself. Stanley would later return to Uganda to rescue Emin Pasha, the beleaguered 'administrator' of the ill-fated Equatoria Province who was trapped north of Lake Albert. Again, what would become northern Uganda was depicted as unstable, brutally chaotic, and now - more ominously under the shadow of the sinister Mahdist state. ${ }^{58}$ Such miscomprehensions proved critical in shaping British perceptions of particular groups, later to become marginalised within the colonial order, while at the same time the Ganda proved themselves much more adept at co-option. The era of European exploration, then, was also that of the British imagination, ${ }^{59}$ and in the years that preceded the appearance of Lugard's IBEAC force in 1890, land was racialised, associated with hierarchies of political and economic order, and centres and peripheries crystallised accordingly. Buganda was indubitably one of the key actors in the region - although the kingdom's dominant position was waning, and Bunyoro was resurgent - and therefore it was understandable that foreigners were drawn to it. Yet this was also a matter of geographical serendipity. Most outsiders, whether Europeans or coastal Arab merchants, arrived in the region from south of Lake Victoria; they either

${ }^{56}$ H.M. Stanley, Through the Dark Continent, 2 vols (London, 1899; 1st ed., 1878) I, 255; and see Stanley's letter to the Daily Telegraph, 15 November 1875, quoted in Ingrams, Uganda, 7-10.

57 R. Oliver, The Missionary Factor in East Africa (London, 1965), Chapter 1, provides a handy narrative overview.

58 The key sources for - and by - Emin Pasha and his relief expedition include: G. Schweinfurth et al. (eds.), Emin Pasha in Central Africa (London, 1888), G. Schweitzer (ed.), Emin Pasha: his life and work, 2 vols (London, 1898), H.M. Stanley, In Darkest Africa, 2 vols (London, 1890), A.J. Mounteney-Jephson, Emin Pasha and the Rebellion at the Equator (London, 1890).

59 For an entertaining and informative overview, T.C. McCaskie, 'Cultural Encounters: Britain and Africa in the nineteenth century', in A. Porter (ed.), The Oxford History of the British Empire, Vol. III: the nineteenth century (Oxford \& New York, 1999). 
marched around the lake on its western side or travelled across it by canoe. Comparatively fewer attempted the more arduous trek from the north, although long-distance trade was also developing in this direction, too, in the course of the nineteenth century. It meant that the Ganda were the region's main gatekeepers, and they generally did very well at both welcoming foreigners - although there were stresses and strains along the way - and imposing themselves on them. From Speke onwards, Europeans were intrigued by this ordered, hierarchical society, with its well-dressed and articulate population, its martial prowess and its broad, straight roads; it was a prosperous, agricultural hub of civilisation - savage, in its way, of course, but everything is relative - in a land of darkness and barbarity, inhabited by bellicose natives living under rudimentary despotisms and, worse, half-naked cattle-keepers. ${ }^{60}$

Thirteen years later after Speke, Stanley came to Buganda and recorded more detail on the kingdom's history, and with rather more panache: the relevant chapter in his book is organised into subsections with such headings as 'Kibaga, the flying warrior', 'Wakinguru, the champion', 'Kamanaya, the conqueror of the Wakedi', 'Suna, the cruel', 'Namujurilwa, the Achilles of Uganda' and so on. ${ }^{61}$ Most interestingly, Stanley's king-list extended to thirty-five names - rather more than Speke had gathered. A fair amount of ink has been spilt on this issue, and indeed on the fact that subsequent king-lists varied in length and order of names; ${ }^{62}$ in sum, this represented a dramatic opening up of the 'historical space', and was driven by the energy with which African informants entered that space. The late nineteenth century was a period of turmoil and fierce political and religious competition which frequently exploded into open violence, as Buganda and Bunyoro clashed on their increasingly volatile borders, Buganda fought

60 The complaint, reflecting a slight exaggeration, that when foreigners came to write about Uganda they invariably wrote about Buganda is not as true as it perhaps once was, but more has probably been written on the history and culture of Buganda than on all the other states and societies in Uganda combined. This was expressed to the author on his first visit to Uganda in 1995, while undertaking doctoral research on, alas, Buganda.

${ }^{61}$ Stanley, Dark Continent, I, Chapter 14.

${ }^{62}$ For example D. Henige, "“The Disease of Writing”: Ganda and Nyoro kinglists in a newly literate world', in J.C. Miller (ed.), The African Past Speaks (Folkestone \& Hamden, 1980); B. Ray, Myth, Ritual and Kingship in Buganda (New York, 1991), 207-9; C.C. Wrigley, Kingship and State: the Buganda dynasty (Cambridge, 1996), 26-7 \& passim. 
a civil war, and then a small group of British army officers arrived, heralding the encroachment of the imperial frontier. These events drove interest in the deep past among both Ugandans and Europeans.

Where Speke and Stanley led, others followed in their historical enquiries, and many of the missionary accounts in particular contained historical information of varying quality and credibility. In the early 1880s, Robert Felkin and Charles Wilson of the CMS wrote on aspects of Buganda's past in their book-length account of ministry and travel in the region; ${ }^{63}$ but it was in the late 1880 s and early 1890 s that there was especially intense scrutiny of Buganda's history in print, against a backdrop of political crisis in the kingdom, and no doubt as part of a missionary-led interventionist lobby. Alexander Mackay and Robert Ashe were foremost in that lobby, and offered insights into the region's history with a view to explaining both its degraded state but also its enormous potential for development, given British civilising intervention. ${ }^{64}$ Meanwhile, official or semi-official representatives of foreign interests published their own accounts of Buganda's historical development - even if, as in the case of Captain J. R. L. Macdonald, these were sometimes cobbled together using Stanley and a handful of other recent European sources. ${ }^{65}$ The German adventurer Karl Peters, who was briefly in Buganda at the beginning of the 1890s in an abortive attempt to secure the area for Bismarck, sought in a rather fantastical thesis to make connections between the Ganda and ancient Egypt. ${ }^{66}$ The British emissary Gerald Portal produced a somewhat more prosaic survey, and was more concerned with the political evolution of the kingdom, depicting an impossibly intricate and hierarchical system which was largely at the mercy ('as in England during the Middle Ages') of particularly charismatic and brutal monarchs. ${ }^{67}$ By the time the missionary John Roscoe, a prolific author and amateur anthropologist, was compiling his own encyclopaedic interpretation of

${ }^{63}$ C.T. Wilson \& R.W. Felkin, Uganda and the Egyptian Soudan, 2 vols (London, 1882); see also R.W. Felkin, 'Notes on the Waganda tribe of Central Africa', Proceedings of the Royal Society of Edinburgh, 13 (1885-6).

64 A.M. Mackay (ed. J.W. Harrison), A.M. Mackay, Pioneer Missionary of the Church Missionary Society to Uganda (London, 1890); R.P. Ashe, Chronicles of Uganda (London, 1894).

65 J.R.L. Macdonald, Soldiering and Surveying in British East Africa (London, 1897).

${ }^{66}$ K. Peters (tr. H.W. Dulcken), New Light on Dark Africa (London, 1891).

67 G. Portal, The British Mission to Uganda in 1893 (London, 1894). 
the precolonial kingdom in the early 1900 s, he was very clear about the possibilities offered by oral history:

[T]aking into consideration the remarkably accurate memories of the people, their graphic power to recount the details of events long past, and their conservatism in religious ceremonies and social customs, the reader will recognise that it is possible to obtain from them a fairly accurate account of past ages. $^{68}$

Built into this expression of wonderment at the 'accuracy' of native history-telling, of course, is the notion that the past (substitutable with 'tradition') was somehow unchanging - which in turn gives it its adhesive social power. Roscoe, who supplied 'raw data' to the Cambridge anthropologist Sir James Frazier, represented the beginnings of semiprofessional ethnographic history, and he replicated his approach to Buganda - focusing on the power of ritual and symbolism in the kingdom's political and cultural development - in later studies of Bunyoro and Ankole. ${ }^{69}$ Meanwhile, this was by no means a monopoly of the Anglican mission, as the wealth of historical detail in Father Julien Gorju's regional survey demonstrates. ${ }^{70}$ Gorju was a leading figure in the White Fathers mission. Some years later, the prolific Italian missionary Father Joseph Pasquale Crazzolara worked extensively on the ethnography and languages of the north, mainly the Luo-speaking peoples. ${ }^{71}$

A historical component - whether implicit or explicit - was critical to the functioning of indirect rule in Uganda, and elsewhere in British Africa, as described most effectively by Frederick Lugard in his 1923 treatise. ${ }^{72}$ In many respects, indirect rule - the preferred principle of imperial governance in much of Africa, whereby colonial administrations governed via local, 'legitimate' elites - involved the recognition and co-opting of indigenous history and 'tradition' into the colonial

$68 \mathrm{~J}$. Roscoe, The Baganda: an account of their native customs and beliefs (London, 1911), 3.

69 J. Roscoe, The Bakitara or Banyoro (Cambridge, 1923); J. Roscoe, The Banyankole (Cambridge, 1923).

${ }_{71}$ J. Gorju, Entre le Victoria, l'Albert et l'Edouard (Rennes, 1920).

71 Notably, see J.P. Crazzolara, A Study of the Acooli Language: grammar and vocabulary (London, 1938) and J.P. Crazzolara, The Lwoo, 3 vols (Verona, 1950-54).

72 F.D. Lugard, The Dual Mandate in British Tropical Africa (Edinburgh \& London, 1923), passim. 
system of hierarchy, deference, history and 'tradition' ${ }^{73}$ The system at least implied some understanding of 'the native's' past - an understanding based, in the Ugandan context, on half a century of European historical writing and, increasingly, on local historical production, as we see further. An example of the supposed conjunction of Ganda and British histories/traditions is the case of King's College, Budo, a public school established by the British in 1905-6 on a hill near Kampala which had also been the site, in the past, of the coronation of Ganda kings. ${ }^{74}$ Terry Ranger proposed that Budo was a striking instance of 'the invention of tradition' in the colonial context; ${ }^{75}$ and although Ranger himself later modified his own 'invention' thesis and cautioned against overstating the case ${ }^{76}$ it is nonetheless noteworthy that historical (sub)consciousness was indeed a critical driver in the formation of the early colonial order.

Of course, this was not all one-way traffic. During this period Africans also created or revised histories, at least partly in response to new political markets and the demand for historical knowledge; Ganda historians themselves would respond to the opportunities presented by the late Victorian epistemological marketplace. Newly Protestant elites responded most successfully to the new opportunities, their intellectual engagement with the British at least as important as their military and political partnership in the 1890s and 1900s. ${ }^{77}$ Yet this needs to be understood not only in the context of the competitive new political marketplace which had opened up as a result of the 'scramble' for Africa but also as coming at the end of a turbulent, often violent, and certainly transformative nineteenth century. Africa's nineteenth century had been an era of stress and change, and it was also characterised by intense historical interest, and continual historicisation. Societies

73 See also D. Cannadine, Ornamentalism: how the British saw their empire (London, 2001).

74 Ingrams, Uganda, 123-5.

75 T.O. Ranger, 'The invention of tradition in colonial Africa', in T.O. Ranger \&

E. Hobsbawm (eds.), The Invention of Tradition (Cambridge, 1983), 221-3.

76 T.O. Ranger, 'The Invention of Tradition Revisited: the case of Africa', in T.O. Ranger \& O. Vaughan (eds.), Legitimacy and the State in Twentieth-Century Africa (Basingstoke, 1993); see also Spear, 'Neo-traditionalism'.

77 See R.J. Reid, 'Ghosts in the Academy: historians and historical consciousness in the making of modern Uganda', Comparative Studies in Society and History, 56:2 (2014) and J. Rowe, 'Myth, Memoir and Moral Admonition: Luganda historical writing, 1893-1969', Uganda Journal, 33:1 (1969), 17-40 \& 33:2 (1969), 217-19. 
sought new ways of investigating, resurrecting and contextualising the past. In an era of upheaval and crisis, it had never been more critical to retrieve certain aspects of the past, and to reflect on their significance. Writing was novel, clearly, in the sense that as a form of representation and expression it was only introduced in the 1870s, and then haltingly; and it only began to become a mainstream (if elite) form of expression in the 1900s. Even so, written expression was, at least in the late nineteenth and early twentieth centuries, only an extension of a rich oral culture. Writing is oral; orality can be written; and the new forms of written text reflected, it can safely be assumed, much deeper cultures of history and testimony which had characterised much of the Ugandan region for a very long time. Still, there was something about the written text that lent itself to permanence and the 'definitive', as various parties sought to affirm long-held (or, indeed, recent) views of the region and the world, as far as it was understood, and it has become commonplace to suggest that because the first written texts introduced into Uganda were scriptures, the written word was associated with essential truth. ${ }^{78}$ Thus our sources for much of this book - for the 'professional' reconstruction of the past - are also themselves key historical actors. They were not autonomous recorders of 'events', detached from the societies on which they wrote; they were partisan political and cultural leaders, for whom historical writing had purpose, and thus the Ugandan writers with whom we will become acquainted were deeply embedded within particular political projects. Yet in another sense they were also historians, not just latent primary sources awaiting a later generation of professional scholars to pick up their works, dust them down and deploy them in pursuit of historical 'truth'. They were scholars, too the forerunners of the Ugandan academicians of the 1960s; and as such one or two of them have made it into the bigger scholarly surveys of global historical writing. ${ }^{79}$ Above all, just as in the nineteenth century there was little distinction between political power and cultural knowledge, so in the early twentieth century there was no separation between historical work and political authority.

The father of African historical writing in Uganda is Apolo Kagwa, who had become katikiro or chief minister of Buganda in 1889 and

78 Again, see Henige, “ "The disease of writing”'.

79 For example, D. Woolf, A Global History of History (Cambridge, 2011), 443. 
who would swiftly emerge as the dominant political figure of the age, both in Buganda and across the wider Protectorate. For Kagwa Protestant convert and close ally of the early British administration the writing of history was not merely the result of political dominance; it was one of its causes, and he seized with gusto the opportunities presented by his acquisition of a printing press which enabled him to create the vision of a Protestant Buganda. Kagwa wrote prolifically about the kings, customs and clans of Buganda, the kingdom which he implicitly or explicitly sought to place at the centre of regional history. ${ }^{80}$ If Kagwa was the pioneer, others quickly followed, though they were not always willing to emulate him uncritically, and debates surrounding a range of historical issues unfurled in the pages of Ebifa mu Buganda ('Events in Buganda'), a monthly journal founded in 1907 by the CMS; and in Munno ('Your Friend'), a rival organ launched by the White Fathers in $1911 .^{81}$ Similar debates and interventions would later regularly appear in the pages of the English-language Uganda Journal, launched in 1934 as the organ of the Uganda Society. Newspapers proliferated in the 1920s and 1930s, too, though many disappeared as quickly as they had appeared. ${ }^{82}$ In the 1930 s, ageing representatives of the generation which had experienced the civil wars and the advent of British rule in the late nineteenth century went into print with an array of memoir, historical work and moral instruction: Albert Lugolobi, Bartolomayo Zimbe, James Miti and Kagwa's one-time secretary Ham Mukasa. ${ }^{83}$

Ganda writers dominated the literary scene in the early decades of the twentieth century, a reflection of - and underpinning - the political order in the British Protectorate. But in time authors from a range

${ }^{80}$ For example, A. Kagwa's Basekabaka be Buganda ('The Kings of Buganda') first appeared in 1901; the most commonly used English edition is that edited by Kiwanuka and published in 1971. Kagwa's Empisa za Buganda ('Customs of the Baganda') appeared in 1907, and his Ebika bya Buganda (dealing with the clans of the kingdom) in 1912.

81 Complete runs of these early journals are available in Makerere University Library.

82 Rowe, 'Myth', 23, 219; Reid, 'Ghosts', 359.

83 Lugolobi's Ekitabo Mbulire ('Let me tell') was written in 1933, Zimbe's Buganda ne Kabaka in 1939 and Miti's three-volume History of Buganda around 1938. Mukasa's three-volume Simuda Nyuma ('Don't turn back') was written over several years, with volumes one and two dated 1938 and 1942 respectively, while the third volume was only rediscovered among his papers in 1964: Reid, 'Ghosts', 360. 
of backgrounds - though invariably from an educated political elite wrote up their own kingdoms' histories with an eye on the present. Y.K. Lubogo sought to carve out space for Busoga in the increasingly competitive political marketplace that was mid-colonial Uganda, and thus wrote up his mammoth history of Busoga between the early 1920s and the late 1930s. He intended to prove that the Soga had been 'a complete tribe for many generations now with firmly established boundaries', even though the narrative recounted extensive inter-clan warfare in careful detail. ${ }^{84}$ In Bunyoro, chief minister Petero Bikunya sought to emulate Kagwa in $1927 ;^{85}$ and the mukama of Bunyoro himself, writing under a pseudonym, tried to put the record straight with a series of more detailed historical essays in the Uganda Journal in the mid-1930s. ${ }^{86}$ A decade later, John Nyakatura, a Nyoro official in the colonial administration, produced his monumental history of Bunyoro in large part to counter the Ganda-dominant historical and political narratives of the late colonial moment, and specifically to address the painful question of the 'Lost Counties' - territory which had been seized from Bunyoro in the 1890s and given to Buganda during the wars of Anglo-Ganda conquest. ${ }^{87}$ At the same time, Princess Lucy Olive Katyanku wrote an admiring biography of Kabalega's son, Andereya Duhaga II, mukama of Bunyoro between 1902 and $1924 .^{88}$ Local historical writing elsewhere in Uganda was slower to develop, but mention might be made here of the first major vernacular study of Ankole, produced by Lazaro Kamugungunu and A.G. Katate in $1955 .{ }^{89}$ Today, it is perfectly common for oral informants to point exasperated researchers in the direction of these great texts - Lubogo, Kagwa, Kamugungunu and Katate, and Nyakatura which have apparently, in some ways, acquired the scriptural status which their authors intended at the outset.

${ }^{84}$ Y.K. Lubogo, A History of Busoga (translated \& unpublished manuscript in Makerere University Library, Kampala, 1960), 3.

85 P. Bikunya, Ky'Abakama ba Bunyoro (London, 1927).

86 The three parts of 'The Kings of Bunyoro-Kitara' appeared in the Uganda Journal between 1935 and 1937.

87 First published in 1947, the most accessible English translation is G.N. Uzoigwe (ed.), Anatomy of an African Kingdom: a history of Bunyoro-Kitara (New York, 1973).

88 Princess L.O. Katyanku \& S. Bulera, The Life of Duhaga II (Nairobi, 1950).

${ }^{89}$ L. Kamugungunu \& A.G. Katate, Abagabe b'Ankole (Dar es Salaam, 1955). 
Yet it was in the 1950s and 1960s that Ugandan history was born as a professional discipline, in line with intellectual developments in Africa - as well as in Europe and North America - more broadly. Much of the work was undertaken by anthropologists and political scientists as well as by a new generation of professional historians, each of whom recognised the significance, and the richness, of the region's past. ${ }^{90}$ And again, Buganda was of particular interest to scholars, owing to its prominence in the body politic, and indeed the comparative wealth of sources available. ${ }^{91}$ But increasingly there was interest - again as much from anthropologists as historians - in Bunyoro, Busoga, Ankole, Lango and Teso, and other, long-neglected parts of the late colonial and early postcolonial state. ${ }^{92}$ These in-depth studies, produced during what may be considered a 'golden age' for Ugandan and African history, greatly expanded the corpus of historical knowledge and interpretation. Moreover, this professional revolution - while instigated to some extent by foreigners - was driven by the Africanisation of the academy, as in the course of the 1960s a new set of Ugandan historians pioneered work on various aspects of the country's past,

90 A.I. Richards (ed.), East African Chiefs: a study of political development in some Uganda and Tanganyika tribes (London, 1959); Ingrams, Uganda; Apter, Political Kingdom; Gulliver (ed.), Tradition and Transition.

91 A selection would include: D.A. Low \& R.C. Pratt, Buganda and British Overrule 1900-1955 (London, 1960), M. Southwold, Bureaucracy and Chiefship in Buganda, East African Studies 14, (Kampala,1961), P.C.W. Gutkind, The Royal Capital of Buganda: a study of internal conflict and external ambiguity (The Hague, 1963), Fallers (ed.), King's Men, M.S.M. Kiwanuka, A History of Buganda: from the foundation of the kingdom to 1900 (London, 1971), Low, Buganda in Modern History, M. Wright, Buganda in the Heroic Age (Nairobi, 1971).

92 L.A. Fallers, Bantu Bureaucracy: a century of political evolution among the Basoga of Uganda (Chicago, 1956, 1965); J.C.D. Lawrance, The Iteso: fifty years of change in a Nilo-Hamitic tribe of Uganda (London, 1957); J. Beattie, The Nyoro State (Oxford, 1971); S. Karugire, A History of the Kingdom of Nkore in Western Uganda to 1896 (Oxford, 1971); D.W. Cohen, The Historical Tradition of Busoga: Mukama and Kintu (Oxford, 1972); J. Lamphear, The Traditional History of the Jie of Uganda (Oxford, 1976); E.I. Steinhart, Conflict and Collaboration: the kingdoms of western Uganda 1890-1907 (Princeton, 1977); J. Tosh, Clan Leaders and Colonial Chiefs in Lango: the political history of an East African stateless society circa 1800-1939 (Oxford, 1978); J. Vincent, Teso in Transformation: the political economy of peasant and class in Eastern Africa (Berkeley, 1982). D. Cohen later edited a set of his original sources in Toward a Reconstructed Past: historical texts from Busoga, Uganda (Baltimore, 1983). 
including Semakula Kiwanuka, Samwiri Karugire and Phares Mutibwa. They often did so under the auspices of the mammoth 'History of Uganda' project run out of Makerere University's History Department, headed in the late 1960s by the dynamic Bertin Webster, which aimed at the retrieval of orally transmitted history by undergraduates and postgraduates in their home districts. ${ }^{93}$ The department's output at this time was remarkable, including major historical work on northern Uganda for the first time, ${ }^{94}$ a series of short books on 'Uganda's Famous Men', ${ }^{95}$ and the Makerere History Papers, published by Longman. ${ }^{96}$ Other vernacular work, aimed at the preservation of the 'traditional', was published under the auspices of the Uganda Literature Bureau. ${ }^{97}$

It might even be argued that Uganda was 'invented', on some levels, as a result of the great Makerere History project: this was the period when the nation was conceived as a historical entity and as the product of African agency in the deeper past as well as in more recent times. The 'History of Uganda' project sought, whether consciously or otherwise, to pull the disparate elements of the nation together and consider the shared experience of being Ugandan. Whether or not it succeeded is perhaps another question, and certainly the events of the next two decades would arguably demonstrate that all the historical work of the 1960s had done was provide the scholarly context for the bloody divisions that would soon open up across Uganda - and which in fact were already opening up even as the Makerere researchers were doing their finest work in the late 1960s and early 1970s. This basic paradox notwithstanding, however, it is worth noting that the especially intense interest in the past in Uganda in the 1950s and 1960s echoed that of the 1890 s and 1900 s, another similarly turbulent era - seeming to

93 C. Sicherman, Becoming an African University: Makerere 1922-2000 (Kampala, 2005), 91-2.

94 J. B. Webster et al., The Iteso During the Asonya (Nairobi, 1973); J.M. Onyango-ku-Odongo \& J.B. Webster, The Central Luo during the Aconya (Nairobi, 1976).

95 For example, A.R. Dunbar, Omukama Chwa II Kabarega (Nairobi, 1965), S.R. Karugire, Nuwa Mbaguta (Nairobi, 1973), M.S.M. Kiwanuka, Muteesa of Uganda (Nairobi, 1967).

96 For example, M.S.M. Kiwanuka, The Empire of Bunyoro-Kitara: myth or reality? (Nairobi, 1968).

97 An example, concerned with the kingdom of Toro, is Y.R.K. Mulindwa \& V.K.K.G. Kagoro, Engeso Zaitu Ez'Obuhangwa [Our Traditions and Customs], (Kampala, 1968). 
validate Jack Plumb's assertion that passions for the past run highest in periods of particular turmoil, even crisis. ${ }^{98}$ The writers and researchers of Uganda's 'golden age' in the middle decades of the twentieth century shared much in common with those historians of half a century earlier. This observation is especially pertinent for local authors, but it holds, too, for their foreign associates.

Idi Amin's coup d'etat in 1971 brought the 'golden age' to an end, effectively, and for much of the next two decades historical research in, and therefore on, Uganda was almost impossible as a result of political turmoil. The History of Uganda project quickly collapsed, in large part through the disappearance of funds from the United States which had supported it. In the course of the 1970s, many of the pioneers of Ugandan scholarship and postcolonial culture fled into exile. The Ugandan cultural, intellectual and literary community was decimated. But in the late 1980s, with the relative stability engendered by the NRM, scholarship was once again possible. In the last quarter century, historians have continued to explore the intricacies of Buganda's evolution, ${ }^{99}$ and, less commonly, modern Bunyoro's travails. ${ }^{100}$ Our understanding of aspects of Uganda's socio-economic and cultural history has become immeasurably richer through work on clans, spiritualism, healing, health and gender. ${ }^{101}$ Others have sought to reconstruct the distinctive experiences of societies in the northern part of Uganda,

98 J.H. Plumb, The Death of the Past (London, 1973; 1st ed., 1969), 33-4.

99 Ray, Myth, Ritual and Kingship; Wrigley, Kingship and State; R.J Reid, Political Power in Pre-Colonial Buganda: economy, society and warfare in the nineteenth century (Oxford, 2002); H. Hanson, Landed Obligation: the practice of power in Buganda (Portsmouth NH, 2003); H. Medard, Le royaume du Buganda au XIXe siècle: mutations politiques et religieuses d'un ancien etat d'Afrique de l'Est (Paris, 2007). Two excellent PhD theses have been produced which seek to explore in depth Buganda's twentieth-century political culture: see J.Earle, 'Political Theologies in Late Colonial Buganda', PhD thesis, University of Cambridge, 2012 and A. Stonehouse, 'Peripheral Identities in an African State: a history of ethnicity in the Ugandan kingdom of Buganda', PhD thesis, University of Leeds, 2012.

100 S. Doyle, Crisis and Decline in Bunyoro: population and environment in Western Uganda, 1860-1955 (Oxford, 2006).

101 N. Kodesh, Beyond the Royal Gaze: clanship and public healing in Buganda (Charlottesville, 2010); D. Peterson, Ethnic Patriotism and the East African Revival: a history of dissent c. 1935-1972 (Cambridge, 2012); R. Stephens, A History of African Motherhood: the case of Uganda, 700-1900 (Cambridge, 2013); S. Doyle, Before HIV: sexuality, fertility and mortality in East Africa 1900-1980 (Oxford, 2013). 
on which much historical research is still needed; ${ }^{102}$ some of the most compelling work has been done by intrepid anthropologists and journalists, particularly with a view to explaining the nature and fallout of the war in the north waged by the Lord's Resistance Army against the NRM state. ${ }^{103}$ In terms of explicitly historical scholarship, a few have dealt with the very deep past, ${ }^{104}$ though most have considered the significance of imperial partition and varied aspects of the colonial experience, and the postcolonial crisis which swiftly followed. ${ }^{105}$ In the last few years, there has been a veritable explosion of writing on Uganda, driven in large part by a new cohort of younger scholars, and some of the central themes are usefully encapsulated in a series of special issues of the Journal of Eastern African Studies. The first considered 'Uganda from the margins', and includes contemporary analysis of northern Uganda as well as the western border. ${ }^{106}$ Another, concerned with 'new themes in Ugandan history', offered insights into sexual behaviour, the politics of intellectual history, the evolution of political identity and colonial-era health policy. ${ }^{107} \mathrm{~A}$ further special issue represented in many ways the most cogent attempt to date to understand the functioning of the state under Idi Amin. ${ }^{108}$ In Uganda itself, a range of themes remain important in terms of scholarly output. Historical biography remains popular - such as Samwiri Lwamga Lunyiigo's recent study of Mwanga, which reads like an attempt to reposition the Ganda alongside the Nyoro as 'resisters', ${ }^{109}$ and work on Edward Mutesa by

102 R.R. Atkinson, The Roots of Ethnicity: the origins of the Acholi of Uganda before 1800 (Philadelphia, 1994); M. Leopold, Inside West Nile: violence, history and representation on an African frontier (Oxford, 2005).

103 See, for example, S. Finnstrom, Living with Bad Surroundings: war, history, and everyday moments in Northern Uganda (Durham NC \& London, 2008), M. Green, The Wizard of the Nile: the hunt for Africa's most wanted (London, 2008).

104 Notably, Schoenbrun, A Green Place, Stephens, African Motherhood, and Atkinson, Roots of Ethnicity.

105 M. Twaddle, Kakungulu and the Creation of Uganda (London, 1993); G. Thompson, Governing Uganda: British colonial rule and its legacy (Kampala, 2003); D.A. Low, Fabrication of Empire: the British and the Uganda Kingdoms, 1890-1902 (Cambridge, 2009).

106 See the various papers in Journal of Eastern African Studies, 6:1 (2012).

107 Journal of Eastern African Studies, 6:3 (2012).

108 Journal of Eastern African Studies, 7:1 (2013).

109 S.L. Lunyiigo, Mwanga II: resistance to imposition of British colonial rule in Buganda, 1884-99 (Kampala, 2011). 
Godfrey Nsubuga and A.B.K.Kasozi. ${ }^{110}$ Charles Peter Mayiga's book on the restoration of Edward Mutesa's son to the throne is written from the author's perspective as the key lawyer involved. ${ }^{111}$ And then there is the burgeoning world of memoir and autobiography, beginning with the President's own life story. ${ }^{112}$ Museveni's autobiography begins with fond recollections of childhood, and a simpler, happier, often rural life, and has much in common with other recent political memoirs - those of Kabaka Edward Mutesa and Princess Elizabeth of Toro - in terms of the romantic imaginings of cattle and countryside, and simple folk, away from the hard complexities and conundrums of modern national politics. ${ }^{113}$ Janet Museveni's life story presents, predictably, the strong campaigning woman of conscience, and reflects the fact that she has her own power base quite distinct from - even in competition with - her husband's. ${ }^{114}$ Their son, Brig. Gen. Muhoozi Kainerugaba, has attempted a military history and wonders if there is indeed an 'African way of war', ranging back to Mbale in 1973 (the year before he was born) and of course up to the great deeds of his father. ${ }^{115}$ Recent memoirs abound: experiences of life under Idi Amin, or under Obote; war memoirs from the NRA bush war, for example by Pecos Kutesa. ${ }^{116}$ Others veer into the realms of hagiography, such as Ondoga ori Amaza's admiring study of Museveni. ${ }^{117}$ At the very least it is a reminder of the darkness that lies just under Kampala's bustling surface. In 2012, a formerly close ally of Museveni published a book 'exposing' the failings of the regime. ${ }^{118}$ Uganda in the 2010s is

110 G. Nsubuga, Sir Edward Muteesa: his life and politics (Kampala, 2013);

A.B.K. Kasozi, The Bitter Bread of Exile: the financial problems of Sir Edward Muteesa during his final exile, 1966-69 (Kampala, 2013).

111 C. P. Mayiga, The King on the Throne (Kampala, 2009).

112 Yoweri Museveni, Sowing the Mustard Seed: the struggle for freedom and democracy in Uganda (Oxford, 1997).

113 Princess Elizabeth of Toro, African Princess: the story of Princess of Elizabeth of Toro (London, 1983); The Kabaka of Buganda, Desecration of My Kingdom (London, 1967).

114 J. Museveni, My Life's Journey (Kampala, 2011).

115 M. Kainerugaba, Battles of the Ugandan Resistance: a tradition of maneuver (Kampala, 2010).

116 P. Kutesa, Uganda's Revolution, 1979-1986: how I saw it (Kampala, 2006).

117 Ondoga ori Amaza, Museveni's Long March from Guerrilla to Statesman (Kampala, 1998).

118 Author's notes and informal interviews, 10 August 2012. 
strikingly reminiscent of the 1930s, in terms of the concerns and interests of that decade, which was also a time when an ageing generation sought to write its place into history and society. There is also a similar interest in entrepreneurs of the past, big men who carved order out of chaos and opportunities for themselves in the wilderness - such as David Bakibinga's admiring study of Daudi Kintu-Mutekanga, who between c. 1900 and 1940 was established as a leading colonial figure, grabbing land and doing profitable business, in the Bugabula district in Busoga. ${ }^{119}$

In sum, there is a wealth of new research to get to grips with: this is scholarship which has continued to add to our understanding of Uganda's historical trajectory, or trajectories; and it is one of the core objectives of this book to pull these various specialist studies together and synthesise their findings, rendering them meaningful in the context of a Ugandan history in all its glorious complexity. It is a sad fact, however, that the vast bulk of the mainstream scholarship on Uganda is now undertaken by foreigners. There are numerous reasons for this, no doubt, but in sum, while the higher education sector in Uganda has stabilised and indeed expanded considerably over the last thirty years, its underpaid, resource-starved and teaching-burdened academic staff have little time for scholarly research. It is also the case that the current emphasis is very much away from the humanities and towards science, technology and business, at least in terms of government funding and encouragement; history, as a discipline, sits ill with the developmental agendas now dominant in Ugandan public life. Discussions about the state of the discipline with historians at Makerere University can be depressing affairs indeed. ${ }^{120}$ The complaints are common, and multiple: students do not want to study history but are often made to; the History Department is largely a service department for secondary school teachers; there is a feeling that history as a discipline is declining in importance and receives no support from the government. ${ }^{121}$ Academic staff, meanwhile, work long hours with huge classes and increasingly lack a research culture; publication is only an option for a few, and then mostly aimed at promotion. ${ }^{122}$

\footnotetext{
119 D. Bakibinga, Daudi Kintu-Mutekanga: administrator and entrepreneur (Kampala, 2006).

120 See also Reid, 'Ghosts'.

121 Author's notes and informal interviews, 6 August 2010.

122 Author's notes and informal interviews, 25 October 2013.
} 
It is certainly an opportune moment to take stock. But it is also the case that since the 1960s, Ugandan historiography has become increasingly balkanised, reflecting a more general trend in Africanist scholarship. Historians, naturally, do what they do best, and focus on specific places at specific times while dealing with specific themes. There are no doubt a number of factors driving scholarly compartmentalisation, which is as much the product of the professional pressures facing historians as of intellectual considerations, but suffice to note here that it has been more than thirty years since the last attempts to produce histories of Uganda as a national entity over la longue durée were published, namely those by Samwiri Karugire (whose account in fact only goes up to c. 1970) and by J. J. Jorgensen. ${ }^{123}$ In the interim, Phares Mutibwa's history covers the period of independence (up to the early 1990s), ${ }^{124}$ while more recently Aili Mari Tripp has produced a fine survey of contemporary Uganda. ${ }^{125}$ The latter is not explicitly a work of history but it offers some useful historical background to a series of current concerns. Otherwise, for large surveys of nineteenthand twentieth-century Ugandan history and the wider regional context, one must revert to the relevant chapters in the ageing History of East Africa, a three-volume set published by Oxford University Press between 1963 and $1976 .{ }^{126}$ Some of these are exemplary in scholarly terms, but they are, inevitably, increasingly out-of-date. Again, this no doubt reflects the specificity of the interests of scholars working on Uganda; but it also, perhaps, reflects a modern disinterest in even a suspicion of - the conceptualisation of African history within the framework of the nation, and may even signify a lack of faith in Uganda itself as a viable unit of study; perhaps even a lack of faith in the nation itself.

123 Karugire, Political History; J.J. Jorgensen, Uganda: a modern history (London, 1981).

124 Mutibwa, Uganda since Independence. 125 Tripp, Museveni's Uganda.

126 R. Oliver, 'Discernible Developments in the Interior, c. 1500-1840' and D.A. Low, 'The Northern Interior, 1840-1884', in R. Oliver \& G. Mathew (eds.) History of East Africa, vol. I (Oxford, 1963); D.A. Low, 'Uganda: the establishment of the Protectorate, 1894-1912', C. Ehrlich, 'The Uganda Economy, 1903-1945', and R.C. Pratt, 'Administration and Politics in Uganda, 1919-1945', in V. Harlow \& E.M. Chilver (eds.), History of East Africa, vol. II (Oxford, 1965); C. Gertzel, 'Kingdoms, Districts, and the Unitary State: Uganda, 1945-1962', D.A. Lury, 'Dayspring Mishandled? The Uganda Economy, 1945-1960', and C. Wrigley, 'Changes in East African Society', in D.A. Low \& A. Smith (eds.), History of East Africa, vol. III (Oxford, 1976). 


\section{Representation and Reverberation}

Uganda's history is reflected in a multitude of things and words, in continually evolving cultural production. Through all the dramas of political upheaval, economic turmoil and social change, Ugandans represented their experiences in cultural forms of staggering variety. They have told and, later, written stories; performed plays; danced to and composed music; carved and painted. The reconstruction of cultural production in the deeper, precolonial, past can be problematic, of course, and the nature of its recovery a matter of serendipity, even irony. Take, for example, the Luzira Head, discovered in 1929 on the outskirts of Kampala together with fragments of other figures. ${ }^{127}$ It has been dated to the ninth or tenth century CE. Made of clay, and apparently part of a pot, the elaborate hair arrangement - which looks like clay worked into the hair - may denote high status, as it was a coiffure associated with religious and political leadership elsewhere. It is regarded as a celebration of power, of leadership - as much subsequent craftsmanship and aesthetic endeavour did in the region. It may, for example, represent emerging power dynamics and structures on the northern shore of Lake Victoria which would eventually lead to the rise of centralised states. It is somewhat fitting, perhaps, that it was accidentally uncovered by the inmates of the nearby Luzira Prison - those who had fallen foul of a very modern form of centralised statehood, the British colonial order - assigned to undertake building work. ${ }^{128}$ More broadly, artistic expression is difficult to historicise. We know intuitively - that art, dance, music, all are part of the human experience, everywhere. But how to measure changes in expression over time in preliterate settings? The first contemporary recordings are in the texts of European observers, in which we are offered glimpses of dancing and drumming, which seemed to all Europeans the very essence of nerve-tingling savagery. Those sources reveal that war was fertile ground for aesthetic representation, as it remained into the twentieth century and beyond. Soldiers in Busongora around Kasese painted their

${ }^{127}$ It has long been a source of fascination, beginning with E.J. Wayland, M.C. Burkitt \& H.J. Braunholtz, 'Archaeological Discoveries at Luzira', Man, 33 (1933), and rather more recently, A. Reid \& C.Z. Ashley, 'A Context for the Luzira Head', Antiquity, 82:315 (2008).

128 T. Phillips (ed.), Africa: the art of a continent (London, 1996), 140, 194-5; W. Gillon, A Short History of African Art (London, 1991), 323-4. 
faces in war - one of the few Ugandan examples of proverbial 'warpaint' - while Nyoro soldiers decorated themselves with animal parts: leopard and monkey skins, cows' tails, antelopes' horns, and the false beards also used by chiefs. ${ }^{129}$ The occasional glimpse afforded by earlier sources notwithstanding, we rely upon the ethnographic work done in the colonial period. From this, it may be possible, to some extent, to extrapolate backwards and trace patterns in the deeper past; but it is a problematic exercise, for the cultures thus collected are very much the product of the moment of their assembly, and inevitably contaminated, to a degree, by colonial representation. This is a question of selection and catalogue and narration. It was precisely the goal behind the establishment of the Uganda Museum to retrieve, preserve and display; and thanks to that project, we have access to a veritable treasure chest of material culture, and countless refractions of Uganda. The same culture of preservation and display is evident in a recent book on African art, in which we see the bonnet of human hair and beads, probably from Acholi, an example of the ornate coiffures associated with warrior initiation. Then there are the headrests of the Karamojong or a related group; and the milkpot from Bunyoro. ${ }^{130}$ And there is evidence, too, of artistic networks following fast on the expansion of commerce in the nineteenth century: craftsmen on Ukerewe Island in the south of Lake Victoria were by the mid-nineteenth century producing distinctive carved figures which appear to have been dispatched to Buganda as diplomatic gifts. ${ }^{131}$ Margaret Trowell - pioneer at Makerere's College of Art - along with her collaborator Karl Wachsmann produced a meticulously detailed and encyclopaedic tome on Ugandan arts and crafts. ${ }^{132}$ But how much can we use these accounts - as typical as they are of the 'colonial library' - to reconstruct a nineteenthcentury scenario, without reifying particular forms of 'traditional culture'? Can anything be said, for example, about the nineteenth century using twentieth-century descriptions of drums and instruments, as was attempted at a pioneering conference at Makerere in 1963 ? $^{133}$

129 Stanley, Dark Continent, I, 183; Baker, Albert N'yanza, II, 80-81.

130 Phillips (ed.), Africa: the art of a continent, 139, $141 .{ }^{131}$ Ibid., 121.

132 Margaret Trowell \& Karl Wachsmann, Tribal Crafts of Uganda (London, 1953).

133 See, for example, First Conference on African Traditional Music, Makerere University College, 15-19 December 1963 (Kampala, 1964). 
External input can be problematic, and complicates the pursuit of 'authenticity' in the recovery of the cultural past. The story of Kasubi is particularly germane in this connection. The site of the royal tombs of Buganda - it contains the graves of Mutesa I, Mwanga, Daudi Chwa and Mutesa II - was badly damaged by a fire in March 2010 which provoked several days of trouble across the kingdom. Kasubi's history exemplifies the struggle around representation, authenticity and legitimacy. Originally built in 1874 , it underwent major reconstruction in 1911, and again in the mid-1930s. On the occasion of each reconstruction, the challenge was - according to what model should it be rebuilt? What was 'authentic' and 'indigenous' and 'traditional'? At some point, and certainly by the 1930s, it became in effect a colonial mausoleum, as Andrew Reid has pointed out; but was that really its original purpose? ${ }^{134}$ It is clear enough that the meanings and significance - and the design - of Kasubi may have changed over several decades, but that the 2010 fire reawakened fierce emotion about heritage and identity at a moment when the kingdom felt persecuted by the state. ${ }^{135}$ In the months following the fire, the key issue has been the importance of local materials in the reconstruction of the tombs, and the identification of local historians and custodians who can advise on design and building. The problem was that between 1967 and 1993, when all kingdoms were abolished, vital skills and knowledge were lost. A search was launched for the special grass to make the thatched roof of the main enclosure, and for those who had the skills for the task. Meanwhile, old men sat around the edge of the ruins, all day, every day, as observers and guardians, making sure that everything proceeded according to convention and custom. Similar challenges in preservation and representation confronted the hard-pressed staff of Department of Antiquities in the 1960s and 1970s, as they struggled to protect historic sites against the predations of robbers and termites. ${ }^{136}$

Yet it seems - in a fascinating example of feedback - that at least some knowledge was to be gleaned from early European sources. At the

134 See Remigius Kigongo \& Andrew Reid, 'Local Communities, Politics, and the Management of the Kasubi Tombs', World Archaeology, 39:3 (2007).

135 Interview, Remigius Kigongo, and site visit, Kasubi Tombs, 9 April 2013.

136 For example: Kabale District Archives, 'Monuments Section - Monthly Report, August 1969', 2 September 1969, \& 'Department of Antiquities Monthly Report, September 1974', 11 October 1974, COM 21, CD24, Culture \& Activities. 
main entrance of the Kasubi site, there was an arrangement of images and information, and plans of the layout; and use was made of the famous picture in Speke's Journal of 'King Mtesa holding a levee' at the entrance of his palace. ${ }^{137}$ In fact this was originally a sketch by Speke's companion James Grant (both he and Speke are in the picture), and then drawn up in published form by the noted German illustrator based in London, Johann Baptist Zwecker. The problem is a fairly obvious one: the accuracy of the detail in Zwecker's final illustration is difficult to verify, and the question is - is the modern kibuga based on Zwecker's picture, or does Zwecker's picture accurately represent the nineteenthcentury kibuga? Then there were later plans and maps, including some from Gutkind's noted studies from the 1950s. ${ }^{138}$ The main building at Kasubi was a burnt-out shell after the fire; the only items still standing were a couple of supporting poles, the red brick wall erected beneath the grass and wattle by the British in 1938 to ensure (they believed) stability, and the iron roof support which dated to the same period. Many were shocked to see these architectural innovations, these manifestations of modernity under the vernacular design. ${ }^{139}$ Those involved in the reconstruction work marvelled at the resolute intervention which had led colonial administrators in the 1930s to bolster the 'traditional' royal palace with bricks and metal: it seemed, in some ways, an apt metaphor for the relationship between Britain and Buganda. 'Tradition', indeed, can be rather more novel than might be assumed. The Gomesi, for example, is celebrated as the 'traditional' clothing for women, and lauded for its enduring appeal, despite modifications over the decades. Yet the Gomesi itself could be traced only to 1905, when its designer - the Goan Indian Caetano Gomes - first launched the dress, and it was only really in 1914, when the Kabaka Daudi Chwa's wife wore one at her husband's coronation, that it entered popular consciousness. ${ }^{140}$ The 'traditional' kanzu outfit for men, meanwhile, at that point did not quite date back a century, and was only introduced in the 1840s and 1850 s by coastal traders, when cotton cloth was increasingly supplanting bark-cloth as the indigenous textile of choice, although throughout the twentieth century bark-cloth continued to be deployed in 'traditional' activity.

137 See Speke, Journal, opp. p.421.

138 The work culminated in Gutkind, Royal Capital.

139 Site visit, Kasubi Tombs, 9 April 2013. ${ }^{140}$ Understand Uganda, 24-5. 
We cannot assess the significance of arts and crafts without noting the socio-political dimensions to both. There was a close association, notably, between forged metal and political leadership, as is clear from the earliest nineteenth-century descriptions of the artefacts kept in royal palaces. Much art was functional in that its chief purpose was to underscore political authority, especially royal power. One of the most clearly manifest instances of this is in the public usage of drums as a central component of material political culture. In Buganda, the mujaguzo was especially significant: this was a set of drums controlled by the kabaka which were used to issue messages across the kingdom, notably in terms of declaring military campaigns and issuing information about soldier collection points. It may have been Kabaka Mutebi - possibly in the mid-seventeenth century - who originated the drums, ${ }^{141}$ but in some form or other they undoubtedly pre-dated this. Other drums were used by senior chiefs, particularly those on military campaign, ${ }^{142}$ while similar sets of drums signifying political leadership were common across the region. They had an especial importance in Nkore where they were known as Bagendanwa and symbolised the kingdom's sovereign independence. ${ }^{143}$ In Bunyoro, as in Buganda, drums were part of the mukama's material estate and he also had a distinctive drum beat in issuing commands. ${ }^{144}$ Art, then, was associated with stable political offices - regalia, chairs, etc., with distinctive visual design celebrating political authority. The association with political office is certainly the most public, visible representation of art that has survived. This was predominantly a male activity. The same is true of working in wood, where in the Ugandan area as elsewhere in Africa there is a link between the craft and the harnessing of spiritual power. Pottery perhaps tells a different story. Changes in pottery style in the deeper past, during the first half of the second millennium, suggested important shifts in social organisation: formerly ornate Urewe ware was probably the preserve of specialist craftsmen, but the simpler ware - apparently carried by pastoralists from the north - was likely made by most households, no longer specialist, and

141 B.M. Zimbe, Buganda ne Kabaka [Buganda and the King], (tr. F. Kamoga, unpublished MS, Makerere University Library, Kampala, c.1939), 19.

142 Stanley, Dark Continent, I, 337, 341.

143 'K.W.', 'The Kings of Bunyoro-Kitara, Part I', Uganda Journal, 3:2 (1935), 156.

144 Speke, Journal, 478. 
was perhaps the work of women. ${ }^{145}$ Then there is cloth - notably bark cloth - which appears to have been predominantly male, though possibly women played a greater role in indigenous textiles. Overall, there was a reasonably clear relationship between gender, power and art or craftsmanship: for several decades into the twentieth century, as in the precolonial period, metal and wood were predominantly male activities and thus the production of things of beauty as well as power were in the realm of masculinity; and it seems fair to suggest that this only began to change in the middle decades of the twentieth century, when women begin to emerge as craftsfolk and artists.

For all these material achievements, Uganda's primary art forms were music, oral poetry and narrative performance, and therefore visual art was very much a product of the twentieth century. ${ }^{146}$ In 1936, Margaret Trowell began organising informal painting classes in her home at Makerere; she was later able to secure funding to establish a Department of Fine Art at Makerere, which became the main centre in East Africa for formal art training. ${ }^{147}$ This was the era in which the international market for African 'tribal' art expanded rapidly; ironically, as Sidney Littlefield Kasfir has pointed out, 'what was potent about African art in the eyes of European artists such as Picasso was derived from a past antithetical to the modernity newly prized in their own work'. ${ }^{148}$ For a number of years the teachers at Makerere had at least partially been trained abroad - the Kenyan sculptor Gregory Maloba, the Tanzanian painter Sam Ntiro, for example - but by the 1970s there had emerged a generation of artists trained exclusively in Africa. In Uganda, as elsewhere, artists sought to capture the excitement and

145 For a useful overview, see C. M. Kusimba \& S. B. Kusimba, 'Mosaics and Interactions: East Africa, 2000 b.p to the Present', in Ann Brower Stahl (ed.), African Archaeology: a critical introduction (Malden MA, \& Oxford, 2005). New work on Urewe culture is continuing under the auspices of the British Institute in Eastern Africa.

146 R.-M. Rychner, 'The Context and Background of Ugandan Art', in Eckhard Breitinger (ed.), Uganda: the cultural landscape (Kampala, 2000), 263. For an excellent history with a grand sweep, see George William Kyeyune, 'Art in Uganda in the Twentieth Century', PhD dissertation, University of London, 2004.

147 Rychner, 'The Context', 264-5.

148 S. L. Kasfir, 'Visual Cultures', in J. Parker \& R. Reid (eds.), The Oxford Handbook of Modern African History (Oxford, 2013), 438. 
anticipation around new nationhood in painting. ${ }^{149}$ As in other spheres the Amin and Obote years took their toll on artistic endeavour, but by the 1990s, the Ugandan art scene was flourishing, led by regularly exhibited artists such as Jak Katarikawe, Lydia Mugambi, Geoffrey Mukasa, Teresa Musoke, Fred Mutebi and Fabian Mpagi. The emergence of a small but successful cohort of female artists was particularly striking, given their previous invisibility in the field. Ugandan painters concerned themselves with the issues which dominated Ugandan public and political life: the devastation of the AIDS epidemic, marital infidelity, political disorder. Some - as in the case of Mpagi's 1994 oil on canvas 'Warriors' - approached distinctively African representation in new, visually powerful ways. This work has to some extent benefited from the continued expansion of the international art market.

It also reflected a growing individualism, with particular artists of note emerging in what had once been - certainly for much of the nineteenth and twentieth centuries - a community activity. Previously, artists and craftsmen had been largely anonymous, although oral histories collected in the early 1900 s contain some brief glimpses into the 'fame' attached to particular workers in metal, or wood, bringing them to the attention of royal court or other chiefly figures. It is also clear that 'traditional' crafts were co-opted in new ways. Bark cloth, for example, was used in painting. ${ }^{150}$ Among the notable instances of this is the use of bark cloth by women's campaign groups seeking to raise awareness of the impact of HIV/AIDS, with large segments of the cloth - once associated with royal power in Buganda, and to some extent elsewhere - being decorated with colourful designs and images. Modern Ugandan art was notable in particular for its vibrant colour, and its depictions of what might broadly be termed traditional scenes with a modern twist, or in a contemporary setting. The art scene, with its centre of gravity, inevitably enough, in Kampala, is arguably more dynamic in Uganda today than at any time since independence and involves a number of particularly celebrated artists who have moved Ugandan visual art decisively away from the utilitarian and towards a more abstract - 'art for art's sake' - deployment of the imagination and

149 See also R. Woets, 'The Recreation of Modern and African Art at Achimoto School in the Gold Coast (1927-52)', Journal of African History, 55:3 (2014). 150 See, for example, the excellent website http://ugandart.com/ 
subjective analysis. This has, perhaps, been the hallmark of the 'cultural revival' of the last twenty years, suggestive of liberation from troublesome 'traditional/modern' dichotomies, and of a more self-confident embrace of histories and cultures.

The central point to emphasise here is that throughout the twentieth century, artists and craftspeople linked past and present in ever more innovative ways, and several generations of them were joined together in a conviction, episodically inherited, that the past mattered, and was, indeed, inseparable from the present. Their work was often explicitly historical, as they sought to portray particular readings of the past, and to retrieve what was regarded at particular moments as valuable and, perhaps, lost. At the same time, they refracted contemporary issues and anxieties through historical depiction, and through stylised interpretations of 'traditional' culture, custom and narrative. The same was true of their literary counterparts.

\section{A Flowering Barrenness}

Taban lo Liyong once famously described East Africa as a literary wasteland. ${ }^{151}$ Taban was a controversial and colourful figure, one of the leading lights of the Ugandan literary scene he so brutally disparaged, admired and lambasted in pretty much equal measure. But he had been one of the most vociferous advocates of the centrality of African oral tradition being positioned at the heart of literature curricula on the continent, and recommended the establishment of a 'counter-curriculum' of African literature which should take priority over 'English literature'. Only after the curriculum had been Africanised could students return to Western literature, which was then to be interpreted from African perspectives. In this he collaborated with Henry Owuor-Anyumba and Ngugi wa Thiong'o. ${ }^{152}$ Ironically, however, much of the indignant opprobrium heaped on Taban consequent to his grim appraisal of the state of the East African literary

151 T. 1. Liyong, 'East Africa, O East Africa, I Lament Thy Literary Barrenness', Transition, 50 (1975), 43. See also 'Lo Liyong -Literary Icon Who Delights in Ruffling Feathers', 21 October 2011, http://allafrica.com/stories/ 201110240408.html

152 'On the Abolition of the English Department', in N. w. Thiong'o, Homecoming: essays on African and Caribbean literature, culture and politics (London, 1972). 
landscape - including from no lesser a figure than fellow Acholi poet and scholar Okot p'Bitek - was based precisely on the fact that Taban had, as Ernesto Okello Ogwang points out, 'restricted his understanding of literature only to the written texts, at the expense of the oral literatures'. ${ }^{153}$

In any case, the period in which Taban made his summary pronouncement was something of a golden age for Ugandan literature. True, Uganda has often been overshadowed by its more celebrated Kenyan neighbour - and it was a shadow cast at the very outset of independence. The Kenyan writer Ngugi wa Thiong'o was a student at Makerere in the late 1950s, where he wrote some of his earliest works, works which Uganda would come to claim as its own, for Ngugi was regarded as having been steeped in the politics and culture of that exciting moment on the eve of independence. And it was a play by Ngugi which was the first by an African to be performed at the Uganda National Theatre in Kampala in 1963, claimed as a landmark moment for 'Ugandan' literature. ${ }^{154}$ But Ugandan poets, novelists and playwrights were coming to the fore, too, wrestling with many of the same issues which gripped their contemporaries in other parts of the continent: decolonisation and 'African' identity; history and modernity; and, in time, the disillusion with postcolonial political culture and the emergence of dictatorship and censorship. Just as the trauma of the colonial experience and the meanings of modernity were the concerns of Camara Laye's L'enfant noir (1954) and Chinua Achebe's Things Fall Apart (1958), so they were, too, of Okot p'Bitek's pioneering Luolanguage novel Lak Tar ('White Teeth'), published in 1953. ${ }^{155}$

There is some question as to whether this amounted to a 'national' culture, given the apparent bifurcation, as Eckhard Breitinger described it, between 'the Acholi North, standing for the form of poetry and epic, and the Baganda South/Centre representing drama and performance' - reflecting a crude ethnic division which was 'instrumentalised with devastating effect for national cohesion, national identity,

153 E. O. Ogwang, 'Ugandan Poetry: trends and features, 1965-1995', in Breitinger (ed.), Uganda: the cultural landscape, 100.

154 'Ngugi wa Thiong'o: he wrote Uganda's independence play', New Vision, 1 February 2012.

155 Remarkably, it was not until 1989 that an English translation appeared, published in Nairobi by Heinemann Kenya. 
and ... cultural development during the years of turmoil'. ${ }^{156}$ And it might be suggested that Okot was arguably Uganda's greatest writer not despite being an Acholi himself, but precisely because of the distinctive 'northern' experience he was able to bring to bear on his writing. Lak Tar dealt with themes to which many Ugandans could relate: in this depressing and at times darkly comic tale, the young Acholi protagonist must travel to Buganda for work to earn money for brideprice, and the novel describes a journey between the expectations of 'traditional', indigenous culture (in this case, gathering together brideprice in order to achieve happiness and fulfilment) and the harsher, uncaring and hazardous world of material modernity, manifest in the dangerous and grimy city of Kampala, brutal working conditions for migrant labourers and criminality on the road. Our young, unfortunate hero is robbed and loses everything, and he returns home empty-handed. Likewise, Okot's greatest work - Song of Lawino (1966), followed by the response, Song of Ocol (1967) $)^{157}$ - is presented in distinctive songstyle Luo, and thus very much the product of Acholi cultural norms. Yet it was again concerned with a set of anxieties and conflicts with which all Ugandans were familiar: in the first song, Lawino, the wife, lambasts her husband for having taken up with a 'Westernized' woman and who has abandoned his traditional culture for all things foreign; and in the second, the husband, Ocol, replies by mocking his own culture and refuting his wife's claims. The struggle to reconcile ideas about 'authenticity' and indigeneity with modernity - the 'foreign' - would be a recurrent motif in much Ugandan writing, and in some respects continues to be.

Writers of various hues, then - poets, novelists, dramatists - reached back into the past in search of questions as well as answers, and the struggle to describe and understand current problems was often framed by historical allusion. Okot was at the centre of a veritable explosion of literary and theatrical output in the years that followed. The work of playwright John Ruganda - especially his plays The Burdens (1972) and The Floods (1980) - captured the conflicts, tensions and ultimately the tragedies of the immediate postcolonial era, including the Amin years, frequently using the private lives of individuals and families as

156 See his introduction to Uganda: the cultural landscape, 9-10.

157 O. p'Bitek, Song of Lawino \& Song of Ocol (Johannesburg, 1984); and see G.A. Heron, The Poetry of Okot p'Bitek (New York, 1976). 
microcosms of larger challenges. ${ }^{158}$ Ruganda himself, like many others, fled Uganda in the early 1970s and produced much of his most important work in Kenya. Ruganda's close contemporary (and fellow Catholic) was Robert Serumaga, whose novel Return to the Shadows was published in 1970, but he was especially celebrated as a playwright and as the founder of the National Theatre Company in 1967. His plays - A Play (produced 1967), The Elephants (produced 1970, published 1971) and Majangwa (produced 1971, published 1974) - were noted for their emphasis on the absurd and their lack of central narrative, but at the same time for their portrayal of a stagnating society under Obote. Under Amin, Serumaga developed a distinctive form of theatre, centred on the idea of the Abafumi, or storyteller, and relying on abstract physical movement, mime and dance which successfully conveyed postcolonial violence and disillusionment but which equally successfully escaped censorship. (Amin himself approved, apparently unaware of the criticism embodied in the form, and even invited Serumaga's troupe to perform at the OAU meeting in Kampala in 1974. Amin referred to it gratifyingly as 'gymnastics'. ${ }^{159}$ Ruganda and Serumaga are widely seen as among the founders of modern theatre in East Africa, and were instrumental in the early development of the National Theatre, housed in a modernist building in central Kampala, as the vehicle for emerging talent in the postcolonial epoch. But dramatic performance was mobile, too, witness the formation of the Makerere Free Travelling Theatre in 1964-5 which brought plays to rural areas. ${ }^{160}$ Samuel Kasule has recently demonstrated that such popular performances can be dated to at least the 1930s, thanks to a corpus of archived Luganda recordings. ${ }^{161}$ At the same time, however, the emergence of new forms of cultural output - alongside more deeply rooted traditions of poetry, song and story-telling - reflected a fundamental social shift: plays and novels, notably, implied relatively larger amounts

158 See, for example, Francis Davies Imbuga, 'Thematic Trends and Circumstance in John Ruganda's Drama', PhD thesis, University of Iowa, 1991.

159 Serumaga was involved in the liberation movement of 1979-80, and served briefly in Yusuf Lule's government - rather incongruously as commerce minister - but died suddenly in 1982.

160 D. Cook, 'The Makerere Free Travelling Theatre: an experimental model', in Breitinger (ed.), Uganda: the cultural landscape.

161 S. Kasule, “'Don't Talk into my Talk”: oral narratives, cultural identity, and popular performance in colonial Uganda', in M. Banham, J. Gibbs, \& F. Osofisan (eds.), African Theatre: histories 1850-1950 (Woodbridge, 2010). 
of 'private' time on the part of an educated, literate cultural elite, while also in some ways signifying the transition - as in the case of art and craft, noted above - from community to individual, and the normalisation of the self. All the while, the past was a critical reference point in literature which was frequently concerned with temporal journeys, whether personal or collective, and with the fundamental struggle to comprehend change.

There is a temptation to see the last thirty years as a kind of rebirth. This is certainly how the NRM would like to have it seen. We need, of course, to exercise caution here. Ugandan social and cultural life did not 'cease to be' between 1971 and 1986 - in fact, in all sorts of ways, it thrived. But there is no question that cultural life fell under some pretty dark shadows during that time, and was as much about survival as full expression; and just because the Movement has since pursued a 'rebirth' agenda does not mean there is not some kernels of truth in the basic idea - that since the late 1980s, Uganda has indeed entered a new period of cultural and artistic expression, arguably unprecedented, and certainly more vibrant than at any time since the 1950s. There was tremendous excitement when in 2014 the Ugandan writer Jennifer Nansubuga Makumbi won the Commonwealth Short Story prize. She evidently took enormous pleasure in proclaiming to a British newspaper: 'This is a dream. For Uganda, once described as a literary desert, it shows how the country's literary landscape is changing and I am proud to be a part of it' ${ }^{162}$ Uganda now had a thriving literary scene including book-buying, book-writing and book-publishing. ${ }^{163}$ Moreover the echoes of the deep past in the making of Ugandan literature were everywhere to behold, as also were the enduring influences of oral tradition: Makumbi's earlier work (as a doctoral student in the UK) had been based on the saga of Kintu, Buganda's culture-hero and mythical founding father. In many ways it was the culmination - or, at least, the latest stage - in Uganda's cultural revival since the 1980s and more especially the 1990s, an era characterised by growing selfconfidence, even self-awareness. Yet it has also been an era in which writers have periodically tested the government's tolerance of dissent

162 See 'Commonwealth Short Story Prize Goes to "Risk-Taking” Ugandan', The Guardian (London), 13 June 2014.

163 'Uganda's “Literary Desert”' Is Back in Bloom', Think Africa Press, 17 September 2013. 
and critique, and forbearance levels have varied according to political mood and context: in October 2012, the Uganda Media Council reflected a particularly heightened sensitivity in government when it banned a play, State of the Nation, for criticising political leadership at a time of celebration organised around Uganda's fiftieth anniversary of independence. ${ }^{164}$ In broad terms, of course, Uganda's literary culture has - naturally enough - long positioned itself as a mirror to society and politics, and novelists, playwrights and poets have long been critics of incumbent regimes. This has been encouraged, no doubt, by the NRM - but only insofar as the critiques have been aimed past regimes and their odious antics. It has proven less tolerant of criticisms aimed at its own record.

A new generation of authors has come of age in recent years. In many ways the founding father of the Movement generation is Timothy Wangusa, whose novel Upon This Mountain (1989) described the colonial-era struggles with 'tradition' and modernity through the eyes of a young man and his imminent circumcision ceremony. In fact Wangusa's first collection of poems appeared in 1977 as Salutations, but it was in the 1990s that he became a leading figure in the Ugandan literary scene - with collections of poems such as A Pattern of Dust (1994), full of historical themes and images, followed by the ambitious Anthem for Africa in 1995, which set Amin's era in the context of Africa's entire modern history, and in 2006 Africa's New Brood, another poetry anthology. ${ }^{165}$ Alongside him, and straddling several decades in a remarkable life, is Austin Bukenya, who was producing his first published work - The People's Bachelor (1972) - in the early years of the Amin regime, and who went on to write his most noted play, The Bride, in 1987; and most recently, reflections on modern environmental concerns, A Hole in the Sky (2013). Hailing from Masaka, in Buddu, Bukenya has often written in Swahili, and draws on Ganda traditions for inspiration for his work. Moses Isegawa, who lives in

164 'Uganda's Media Council Bans State of the Nation Play', BBC News, 31 October 2012.

165 There is more to Wangusa than his literary output. He is an academic - he played a leading role in the creation of the department of Languages and Literature at Uganda Christian University in Mukono, and has been vice-chancellor of Kumi University in eastern Uganda - and has served as 'literary advisor' to the Ugandan President, demonstrating Museveni's enthusiasm for the co-option of a range of talent. In 1989, moreover, Wangusa was elected MP for Bubulo County in Mbale. 
the Netherlands, represents a younger cohort of gifted and dynamic Ugandan writers. His Abyssinian Chronicles (first published in Dutch in 1998, and then in English two years later) is his most famous novel, and won great acclaim in the years after its appearance - in many ways it defies summary, but in broad terms it is a tumultuous story of modern Ugandan life. It rather overshadowed his second novel, Snakepit (1999, 2004), which was set in Amin's Uganda and dealt with the themes of corruption and dictatorship. While many of the older generation returned to Uganda in the late 1980s, Isegawa went in the other direction: born into a middle-class Catholic family in Kampala (and thus belonging to a lengthening Catholic literary tradition in Uganda), he left for exile in the Netherlands in 1990, though he returned to Uganda in 2006. Still, there is a conception among some, at least, that the Ugandan 'creative industries' remain somehow defined by their emulation of European models, and perhaps even by the desire to win approval from Western audiences. At an event at Makerere organised to mark the death of Nigerian writer Chinua Achebe, a senior figure in academic administration made the point that 'as we become more and more removed from our culture, we become less creative [italics added]' .... ${ }^{166}$ It seems, given the canon of literature which Uganda has produced in recent decades, an unnecessarily glum reading of the situation.

And so, too, in the realm of popular media, where in Uganda - as elsewhere across the continent ${ }^{167}$ - there has been a veritable flourishing of reportage, analysis, opinion and argument, of multiple visions of the nation, over the last half-century or more. The years after the Second World War witnessed the emergence of the first truly 'national' newspapers - the Uganda Argus was founded in 1955 as the main organ of the colonial administration - and newspapers became ever more important as 'national' organs but in pursuit of particular agendas or political visions. In time, after independence in 1962, it became ever more important for the government to control the interpretation of events and the flow of information relating to them. Soon after the NRM seized power, the New Vision newspaper was launched - it was basically a relaunch of the old Uganda Argus - as the government

166 Author's notes and informal interviews, 6 April 2013.

${ }^{167}$ For an excellent overview, see J. Brennan, 'Communications and Media in African History', in J. Parker \& R. Reid (eds.), The Oxford Handbook of Modern African History (Oxford, 2013). 
organ. In the 1990s, however, the print media scene opened up somewhat, with the founding of the independent Daily Monitor in 1994, and a few years later by the rather more salacious tabloid Red Pepper, launched in 2001. The Pepper appealed to the baser, more populist trends in Ugandan society, and would quickly become a thorn in the side of the government for its printing unseemly gossip about the antics of the NRM's top officials. Television broadcasting was also privatised, and the decade following Museveni's seizure of power in 1986 witnessed the launch of new channels alongside the government's own. Alongside these English-language initiatives in print media and broadcasting, there have been similar initiatives in the vernacular: newspapers such as Bukedde (Luganda), Orumuri (Runyoro), Etop (Ateso) and Rupiny (Luo) are published by the Vision Group, and there are others, each with powerful and occasionally provocative historical visions to promote and historical cultures to celebrate. ${ }^{168}$

Museveni appeared, for a number of years, to self-consciously welcome this robust new media, and had equally robust - even joking relationships with newspaper editors, journalists and broadcasters. But in recent years there have been signs that the putative renaissance is under strain. ${ }^{169}$ The President has become increasingly irritated by their tendency to criticise, and to run stories detrimental to his carefully crafted media image. There are worrying signs that he no longer believes a 'free press' is all it is cracked up to be, and has shown himself willing to use security forces to move in on wayward editors and journalists. The latter know, then, that history is a vital tool in social comment and political analysis, and as in other avenues of literary and aesthetic life, Ugandan print media is notably given to historical reflection, and frequently revels in discussions about the lessons and the precedents of the past. Historical reference points may remain relatively recent - most lie in Uganda's tumultuous twentieth century but journalists, no less than their comrades in the arts and literature, are possessed of a historical consciousness which is invariably used to chastise, critique, even ridicule, on various sides of the political divide. It is this which often irritates those in power, when they are on the

168 See 'A Mixed 50 Years for Uganda's Print Media', in Independent Uganda, $342-7$.

169 B. Tabaire, 'The Press and Political Repression in Uganda: back to the future?', Journal of Eastern African Studies, 1:2 (2007). 
receiving end, though they are themselves no strangers to the deployment of strident historical vision in print and broadcast.

What is clear enough, however, is that representation and expression - whether spoken, sung, performed, written, sculpted - have been absolutely critical, from the precolonial to the modern eras, in enabling people to think about the past and its relationship to the present; to imagine the future; and to seek solace in that imagination. It has enabled Ugandans to interpret and represent tyranny, for example, while also offering protection and escape from that tyranny. It seems reasonable to suggest that the momentum towards a robust and critical commentary on Uganda's past and present, as well as its future direction, while always vulnerable to setbacks, is now unstoppable. 